\title{
Development and maintenance of a telescoping debris flow fan in response to human-induced fan surface channelization, Chalk Creek Valley Natural Debris Flow Laboratory, Colorado, USA
}

\author{
Authors: T. Wasklewicz ${ }^{a^{*}}$, C. Scheinert ${ }^{\mathrm{b}}$ \\ a East Carolina University, Department of Geography, Planning, and Environment, \\ Greenville, NC 27858, USA \\ b The Wooten Company, 350 North Cox Street, Suite 26, Asheboro, NC 27203, USA \\ ${ }^{*}$ Corresponding author. Tel.: +1 252-328-5192; Fax: +1 252-328-6054; E-mail: \\ wasklewiczt@ecu.edu.
}

\begin{abstract}
Channel change has been a constant theme throughout William L. Graf's research career. Graf's work has examined channel changes in the context of natural environmental fluctuations, but more often has focused on quantifying channel change in the context of anthropogenic modifications. Here, we consider how channelization of a debris flows along a bajada has perpetuated and sustained the development of 'telescoping' alluvial fan. Two-dimensional debris-flow modeling shows the importance of the deeply entrenched channelized flow in the development of a telescoping alluvial fan. GIS analyses of repeat (five different debris flows), high-resolution $(5 \mathrm{~cm})$ digital elevation models (DEMs) generated from repeat terrestrial laser scanning (TLS) data elucidate sediment and topographic dynamics of the new telescoping portion of the alluvial fan (the embryonic fan). Flow constriction from channelization helps to perpetuate debrisflow runout and to maintain the embryonic fan and telescoping nature of the alluvial fan complex. Embryonic fan development, in response to five debris flows, proceeds with a major portion of the flows depositing on the southern portion of the embryonic fan. The third through the fifth debris flows also begin to shift some deposition to the northern
\end{abstract}


portion of the embryonic. The transfer of sediment from a higher portion of the embryonic fan to a lower portion continues currently on the embryonic fan. While channelized flow has been shown to be critical to the maintenance of the telescoping fan, the flow constriction has led to higher than background levels of sediment deposition in Chalk Creek, a tributary of the Arkansas River. A majority of the sediment from each debris flow is incorporated into Chalk Creek as opposed to being stored on the embryonic fan.

Key Word: alluvial fan evolution; 2D debris-flow modeling; terrestrial laser scanning; geomorphic change detection

\section{Introduction}

Alluvial fans represent important permanent (Thomas, 2003) and temporary (Hashimoto et al., 2008) sediment sinks within many environmental settings. Sediment delivery to, internal transport within, and sediment delivery from an alluvial fan are important geomorphic agents of environmental change within the piedmont/basin or piedmont/trunk-stream compartments of a landscape. As society has expanded onto piedmont areas, alluvial fans are frequently modified in a variety ways: through development (i.e., housing, resorts, industrial facilities, etc.), hazard mitigation (i.e., sediment retention basins, baffles, cement-lined channels, etc.), and construction of infrastructure (i.e., roads, transmission lines, trails, etc.). These modifications have the potential to alter the long-term sediment delivery to the alluvial fan and hence the evolution of the alluvial fan (Colombera and Bersezio, 2011). The role of human's modifying alluvial fan development has not been widely investigated or quantified within the scientific literature. Here, we examine how human-induced channelization of an 
alluvial fan has developed and maintained the telescopic expansion of a debris-flowdominated alluvial fan. Geomorphic change detection (GCD) from five different debris flows over a three-year period provide real-world constraints on modeling the evolution of the embryonic fan and the contribution of sediment from the telescoping fan to an adjoining tributary of the Arkansas River.

The research presented in this article is associated with a special volume honoring the contributions and influences of William L. Graf over his research and teaching career in geomorphology. The following review of Graf's work is not meant to slight others whom have done extensive research in these areas, but rather to highlight what influences Graf has had on the authors' approach to examining the evolution of geomorphic processes and forms through space and time. We acknowledge that our work examines different geomorphological processes (debris flows as opposed to fluvial flows) and surficial features (alluvial fans as opposed to rivers), but the field-tradition associated with the majority of Graf's research and the assessment of historic spatialtemporal variability in geomorphic systems and their interactions with humans and human development remain a hallmark of his scholarly legacy.

Graf is often cited for his field-based studies on the fluvial transport and storage of heavy metals (Graf, 1985) and radionuclides (Graf, 1996) and the impacts of large dams on riverine ecosystems (Graf, 2005, 2006). However, another constant research theme throughout his career has been investigating the role human modifications play in fluvial processes and forms. Graf's work ranged from the impacts of mining (Graf, 1979) to the effects of suburbanization (Graf, 1975) to the role of urbanization (Graf, 2000) on channel change. A constant in his work has been the use of spatiotemporal data sets such as aerial photography, historical photography, or historical maps to capture channel changes. Our work embraces a similar spatio-temporal approach, but focuses on much higher spatial resolution data (5 cm digital elevation models; (DEMs)) and shorter 
temporal resolution data (event-based mapping). Furthermore, our analyses are able to expand beyond just an understanding of how the human modifications of alluvial fan development leading to telescoping alluvial fan behavior. The human modification (channelization of the bajada) is removed and the long-term development of the embryonic fan and telescoping nature of the broader alluvial fan are investigated in the absence of the human disturbance with the aid of a two-dimensional debris flow model.

\section{Alluvial fan evolution}

Landform and landscape evolution studies in geomorphology involve quantification and theoretical characterization of topographic changes produced by natural and anthropogenic processes (Tucker and Hancock, 2010). Alluvial fans are semiconical landforms commonly found at the edge of valleys (river valleys or faultcontrolled valleys) and are composed of sediment gravity flows, sediment fluid-gravity flows, or some combination of the two delivered from relatively steep, narrow feeder streams (Volker et al., 2007; Wasklewicz et al., 2008). Regardless of the type of flow, flow initiation is often associated with high-intensity rainstorms or prolonged rainstorms.

Fluvial flows are often classified as sheetfloods or channelized flows. Sheetfloods, sediment-laden flash floods, expand outward as they move downfan because the feeder channel no longer constricts them. Channelized flows are constrained to the preexisting channels near the fan apex and often incise rectilinear channels within the upper part of the alluvial fan (Wasklewicz et al., 2008). Channelized flows may give way to sheetflooding or a more distributary flow pattern in the mid-fan or lowerfan.

Debris flows are a common source of material associated with long-term alluvial fan development. Sand, gravel, and boulders constitute the main sediment content in 
debris flows. Clay is also an important component of the debris flow but often contributes $<10 \%$ of flow accumulation (Iverson, 1997). Debris flow initiation can result from a variety of processes: conversion of a shallow landslide (Takahashi, 1981; Costa, 1984; Iverson et al., 1997); impulsive loading from hillslopes (Bovis and Dagg, 1992); entrainment via fire-hosing at the interface between bedrock and colluvium in the source areas (Johnson and Rodine, 1984; Coe et al., 2008); dry ravel entrainment via overland flow entering into gullies (Gabet and Bookter, 2008); and progressive bulking of sediments stored along the drainage network (Cannon et al., 2003). One or more of these initiation mechanisms can be associated with debris flows that deliver materials to alluvial fan surfaces.

Wavelike flow patterns are often present in debris flows (e.g., Beaty 1963; Okuda et al., 1980; Okuda and Suwa. 1981; Ohmori and Shimazu, 1994; Hungr, 2000;

Hürlimann et al., 2003; Imaizumi et al., 2005; McCoy et al., 2010). Watery flows (slurries) precede or follow surges in the feeder channel and on the fan surface. Watery flows can produce significant erosion along the alluvial fan surface (Harvey, 2002). Debris flow erosion within the channel has been recently linked to the passage of the granular debris flow front (Berger et al., 2011) and is likely associated with coarse sediment impacting the bed. Scour depth is also positively correlated with bed water content (McCoy et al., 2010, 2011; Iverson et al., 2011).

Early research hypothesized debris flows deposited when dewatering thinned the flow and/or a reduction in alluvial fan slope caused plastic yield strength to equal shear strength (Johnson, 1970). Debris deposition has also been associated with debris flows overtopping channels or debouching from channels onto the alluvial fan surface (e.g., where the feeder stream meets the fan surface or at the intersection point) where depth decreases (Johnson, 1970; Johnson and Rodine, 1984; Hooke, 1967, 1987; Whipple and Dunne, 1992). Both of the aforementioned flow modifications likely decrease 
velocity thereby enhancing deposition. Alternatively, grain-contact friction and bed friction occur at locations where high pore-fluid pressure decreases or is absent (Major and Iverson, 1999). Decreases in pore-fluid pressure leads to frictional resistance at debris flow margins and promotes levee formation as well as debris dams and snoutslike deposits at the surge margin (Major and Iverson, 1999).

Sediment transport via one or more of the previously described processes changes the alluvial fan topography over time and space. Alluvial fan topographic responses to sediment transport are often represented via three distinct, but often interconnected ways: vertical accretion, lateral accretion, and progradation. The scale of these topographic changes can be on the order of fine-scale changes such as particle roughness (Frankel and Dolan, 2007) or coarse-scale topographic changes associated with fan-lobe formation (Franke et al., 2015) or fan segmentation (Hooke and Dorn, 1992).

\subsection{Alluvial fan development by vertical accretion}

Vertical development and accumulation of mass within many alluvial fans has often been linked to debris-flow deposition (Hooke, 1967; Volker et al., 2007). Debrisflow accumulation is particular prominent in This is particulary the case in stepp, small or intermediate size drainage basins (Wasklewicz et al., 2008; Scheinert et al., 2012). Fluvial processes have also been noted to cause vertical development and mass accumulation (Blair and McPherson, 1994). Larger drainage basins may also produce a combination of debris flows and fluid flows that are important to the long-term evolutions of associated alluvial fans (Volker et al., 2007). Debris-flow deposition is often associated with vertical accretion in the proximal portion of the fan earlier in the fan development, although if debris flows remain the dominant formative process they will 
runout the entire length of the alluvial fan (Suwa and Okuda, 1983; Staley et al., 2006). Over the history of alluvial fan development, fluid flows may begin to dominate and in this case the debris flow deposits are eroded, eroded and left as a fan segment, or buried by distributary or shallow incised channel deposition. The shallow incised channels often form via cut-and-fill processes that leave behind a series of smaller inset terraces (Wasklewicz et al., 2008). Distributary or incised channel deposition has also led to vertical accretion in the middle and distal portions of the alluvial fan as the alluvial fan progrades (Pope et al., 2008; Blair and McPherson, 2009).

\subsection{Alluvial fan development by lateral accretion}

The semiconical form of an alluvial fan is often accounted for by shifts in the locus of deposition. Alluvial fan expansion by the addition of material from these lateral shifts is referred to here as lateral accretion. Lateral accretion is often restricted by the available accommodation space (Viseras et al., 2003). Accommodation space is limited by adjacent topographic structures such as a river valley, ridges or spurs extending out from the mountain front, or adjacent alluvial fans coalescing to form a bajada. Given adequate accommodation space, lateral shifts in the locus of deposition are possible and can result from multiple mechanisms.

A common mechanism by which lateral shifts occur is a channel avulsion (Field, 2001). Channel avulsions occur on alluvial fans formed by fluvial processes (Bryant et al., 1995; Mills, 2000; Field, 2001; Davies and Korup, 2007) and debris-flow processes (Beaty, 1963; Costa, 1984). Hooke (1967) in his seminal physical modeling and field observations as well as other studies (Hooke and Rohrer, 1979; Zimmermann, 1991; Clarke et al., 2008; Nicholas et al., 2009) have noted that the importance of multiple shifts in the locus of deposition is critical to the distribution of sediment across the 
alluvial fan surface. The shifts produced lateral accretion as well as vertical development. Hooke and Rohrer (1979) and Zimmermann (1991) noted that after multiple debris flows deposited sediment to an undetermined height, subsequent debris flow channels avulsed and deposited on topographic lower portions of the alluvial fan or flume/stream table. These topographic locations would either be new segments in the available accommodation space or deposition that would build on an existing alluvial fan surface. This process would then be repeated to produce the conic fan shape of an isolated alluvial fan and large variations in alluvial fan slope across the alluvial fan surface. Similar patterns of alluvial fan adjustment have also been identified in experimental alluvial fans built from fluvial events (Clarke et al., 2008; Nicholas et al., 2009). Hooke and Rohrer (1979) referred to this phenomenon as a high-low effect, whereby sediment deposition builds to an undetermined height and is diverted to repeat the process on another section of the modeled alluvial fans.

\subsection{Alluvial fan development via progradation}

The progradation of an alluvial fan results from multiple mechanisms working either independently or in conjunction with one another to cause flows to emerge farther away from the mountain front on the piedmont or alluvial fan surface. A key component to alluvial fan progradation is the available accommodation space (Harvey, 1984; Calvache et al., 1997; Viseras et al., 2003; Robustelli et al., 2005; Weissmann et al., 2005). Alluvial fan progradation can also occur when the accommodation space restricts the fan's lateral expansion and forces flows farther down the alluvial fan surface, often promoting a more elongated alluvial fan morphometry.

Fanhead trenching, common on many alluvial fans, also shifts flows to the midor distal-fan regions (Harvey, 1978, 1984, 2005). Fanhead trenches can be shallow and 
short-lived or can manifest as deep, incised trenches that have long-lasting impacts on alluvial fan development. Deeply incised trenches have been linked to external controls such as tectonics (Price et al., 2002; Pope et al., 2008), climate change (Harvey, 2005), or base-level lowering (Harvey, 2002, 2005). Experimental laboratory work in conjunction with field analyses (Clarke et al., 2008, 2010; Nicholas et al., 2009) as well as numerical modeling experiments (Coulthard et al., 2002; Coulthard and Van De Wiel, 2007; Nicholas and Quine, 2007a;b; Pepin et al., 2010) have shown that fan incision is not driven purely by extrinsic controls. Rather, internal variations in flow configuration, aggradation and degradation, and variations in sediment delivery rates often promote extensive and deep channel incision. In a similar ilk, historical contingency in the alluvial fan drainage basins has also been cited as a controlling factor in whether an alluvial fan is deeply incised or shows only minor incision (Dühnforth et al., 2008; Fuller and Marden, 2011). Alluvial fan incision has also been linked to anthropogenic activity (Colombera and Bersezio, 2011). Colombera and Bersezio (2011) posited that a dam, built upstream of the alluvial fan, starved sediment loads in the water flow and likely induced rapid incision of the alluvial fan surface.

Regardless of the causal mechanism of the incision, it often produces deposition in the mid- or distal-fan and stimulates the formation of a new embryonic fan or depositional lobe. In cases, where the old fan segment is entrenched enough that no new deposition occurs on the old fan surface, a new embryonic fan will form. The new embryonic fan builds over time at the distal edge of the old fan and gives an alluvial fan the morphometric appearance of segments of a telescope. Blissenbach (1954; also a classic diagram presented in Bull, 1977) was the first to define telescoping or telescopic alluvial fans, and numerous authors have adopted this terminology and shown the widespread nature of telescoping alluvial fan complexes (Ritter et al., 2000; Colombo, 2005; Spelz et al., 2008; Ferrier and Pope, 2012). Herein, we define telescoping (based 
on our interpretation of the literature and field experiences) to be an alluvial fan segment in front of an existing segment that has formed from a deeply incised channel debouching from an older alluvial fan segment. Channel entrenchment does not always lead to a telescoping fan complex; rather a complex of alluvial fan segments develops maintaining the intact semiconical alluvial fan form (Hooke and Dorn, 1992; Mills, 2000; Ritter et al., 2000). The key difference is that the telescopic fans develop segments in front of the older segment. The telescoping nature of the fan can continue for several segments.

Fanhead entrenchment likely plays an important role in sediment deposition beyond the toe of an existing alluvial fan. However, relatively little research has been done on the causal mechanisms leading to and sustaining the telescoping nature of alluvial fan development. Furthermore, we could find no research investigating the telescopic nature of alluvial fan development in the context of humans developing a deeply incised channel to protect developments and infrastructure on the alluvial fan. The current study fills a portion of this gap in the literature by using two-dimensional debris-flow models to show the importance of the human-induced, deeply incised channel to the development of an embryonic fan in a telescoping alluvial fan. Our work also advances the understanding of how embryonic fans develop over several debris flows captured during the field portion of our study. The combination of the two results provides new insights into telescopic alluvial fan development in natural and humanmodified systems, much in the same vain as Graf's work within riverine environments.

\section{Study site}

The Chalk Cliffs are located in the Sawatch Mountain Range of Colorado on the northern extent of the Rio Grande Rift and normal faulting is a dominant component in 
the generation of relief (Fig. 1). Hydrothermal activity has resulted in the alteration of the quartz monzonite that composes the Chalk Cliffs area (Coe et al., 2008) and produced bedrock that is fractured and highly friable. Fractured and highly weathered bedrock has led to steady raveling processes and to the production of thick colluvial deposits in the source area of the alluvial fan under investigation (Fig. 1).

The source area for the alluvial fan is a small semiarid drainage basin (drainage area of $\sim 0.3 \mathrm{~km}^{2}$ ). Many colluvial slopes in the upper and middle portions of the drainage basin are at the angle of repose, and above these slopes is exposed, highly fractured bedrock (Fig. 1). The elevation of the east/west basin confluence that forms the main trunk stream draining the basin is $2767 \mathrm{~m}$, and the elevation for the embryonic fan is $2519 \mathrm{~m}$. Channels within the upper half of the basin are composed of bedrock steps, bedrock-constrained channels with a thin layer of colluvium or debris flow deposits, or thick deposits of colluvium and in some instances these colluvial deposits are interspersed with thick debris flow deposits (debris flow snouts that did not leave the drainage basin). Channels in the lower half of the basin are all composed of thicker deposits of colluvium, alluvium, and debris flow material.

Debris flows are the dominant alluvial fan formative process in the Chalk Cliffs vicinity. Typically, one to four debris flows occur per year within the basin under examination in the current study (Coe et al., 2010). The debris flows form via a firehosing effect in the upper portion of the basin (Coe et al., 2008). Further materials are added to the flow via progressive bulking of materials along the channel in the drainage basin (McCoy et al., 2010, 2011; Staley et al., 2011). Short-duration rainstorms initiate a majority of the debris flows (McCoy et al., 2011). Not all debris flows from the basin arrive on the fan surface; in 2009 only one of the four debris flows debouched onto the bajada and embryonic fan surfaces. The other three events were stored in the upper and middle sections of the channel above the alluvial fan (McCoy et al., 2010, 2011, 2012). 
Debris flows debouching from the feeder channel have formed a large alluvial fan $\left(0.69 \mathrm{~km}^{2}\right)$. The alluvial fan coalesced with other alluvial fans emanating from adjacent drainage basins and is part of a large bajada complex formed during the Holocene after deglaciation of the Chalk Creek valley (Coe et al., 2008). A cabin was built on the alluvial fan in 1898 (information from the Coffee County tax assessors office), and various buildings and homes were built on the bajada in the 1950s. Several buildings on the north side of the channelized portion of the bajada are at risk of debris flows. The channel was excavated along a majority of the alluvial fan to reduce the risk and constrain the debris flows and to force them through a concrete channel crossing on CCR162 (Fig. 1). Channelized flow through the alluvial fan has led to the formation of a telescoping fan, with the new embryonic fan occurring in the Chalk Creek floodplain. A total of five debris flows were recorded on the fan between May 2009 and July 2011 (Table 1). Our initial measurement (29 May 2009) of the embryonic fan showed the area to be $2863.78 \mathrm{~m}^{2}$. The embryonic fan area averaged $\sim 2848 \mathrm{~m}^{2}$ and had an average slope of $0.10 \mathrm{~m} / \mathrm{m}$ over the period of study. Limited accommodation space combined with erosion of the embryonic fan toe via spring floods in Chalk Creek produce an embryonic fan that is much smaller than the upper fan segment.

\section{Methods}

\subsection{Repeat high-resolution topographic data}

Two terrestrial laser scanners (Leica ScanStation 2 and Leica C10) were used over the duration of the study to gather repeat high-resolution point clouds of the changing embryonic fan topography. Common reference points (a combination of temporary and permanent $15.25 \mathrm{~cm}$ planar circular Leica targets) in the field-of-view 
aided in the registration of multiple point clouds gathered from eight to twelve scanner positions during each survey campaign (the number of scanning positions varied with size and complexity of the changing embryonic fan). Permanent targets were located on buried rebar near the fan apex, and temporary targets were positioned at different locations on the fan depending on the fan complexity and dimensions. Seven fieldsurveying campaigns were performed over the study period. The maximum scanning distance in each of the field-surveying campaigns did not exceed $75 \mathrm{~m}$ because of the positioning of the scanning locations and complexity of the embryonic fan topography.

Point cloud registration was performed in Leica's Cyclone software with all registrations not exceeding $5 \mathrm{~mm}$ of error. A lack of dense vegetation on the fan surface negated a need to filter or segment the point cloud. In situations where vegetation was encountered (measurement of fan toe changes), the vegetation was manually removed in Cyclone. Our uncertainty assessments followed methods described in Staley et al. (2014) and provided an assessment of the accuracy of the point cloud data and derived surface for each survey, propagating the uncertainty from both surveys into the geomorphic change detection (GCD) and determining the significance of the propagated uncertainty on volumetric measurements obtained by the GCD (Table 2). A minimum detection level of $1 \mathrm{~cm}$ was used in the evaluation of topographic and volumetric changes, which represents a conservative measure given results from previous work using similar surveying techniques (Staley et al., 2014; Wester et al., 2014). The point clouds were converted to $5 \mathrm{~cm}$ planimetric resolution DEMs using ArcGIS v. 9.x and 10.x.

\subsection{Two-dimensional debris-flow modeling}

We use Flo-2D, a volume conservation model developed to propagate a debris flow to its maximum extent along a topographically controlled path (O'Brien et al., 1993), 
to investigate debris-flow behavior in the presence and absence of the excavated channel. A main goal of this endeavor was to assess the control of channelization of flows on debris flow runout and the maintenance of the telescoping alluvial fan under investigation. The model assumes Bingham plastic rheological behavior and most natural suspensions exhibit this behavior as their shear rates are often found between 1 and $5 \mathrm{~s}$ (Sosio et al., 2007). Debris flows often exhibit shear rates in the range of 1-10 s (Johnson, 1970; O’Brien and Julien, 1988; Phillips and Davies, 1991; Iverson, 2003; Sosio et al., 2007), and McCoy et al. (2012) showed that debris flows occurring with the Chalk Cliffs Natural Debris Flow Laboratory often have shear rates approaching $10 \mathrm{~s}$ during the passing of coarse debris flow surges. These findings provide strong evidence for the general applicability of assumed Bingham plastic rheological behavior and the use of Flo-2D in the current study.

Here, we use a discretized debris-flow hydrograph produced from stage data collected at the lower sonic stage gauging station described in McCoy et al. $(2011,2012)$ for the September 2009 debris flow at the site (Figs. 1 and 2). No velocity measures exist at the lower gauge. An average travel velocity for surge and intersurge flows is adopted to approximate velocity between the middle and the lower gauging stations. The time differences between the surge fronts and the time difference between the start of the inter-surges and the distance between the middle and lower stations are used to provide a rough approximation of velocity (velocity = time difference between arrival of surge fronts or start of the inter surges at middle and lower/ travel distance). The intersurge velocity determined from this approach is maintained consistently throughout the intersurge flows. A minor complication in measuring the start of the surges and intersurges is input from an ungauged tributary upstream and, as such, some velocities may overestimate velocity. However, our velocities would seem to be in accordance with measurements described in McCoy et al. (2010, 2011, 2012). Width and depth 
measurements to finalize the discharge-time hydrograph are developed from a static cross section measurement taken with the TLS prior to the debris flow (Fig. 2). McCoy et al. (2012) showed intersurge flows generally had bulk densities $>1300 \mathrm{~kg} \mathrm{~m}^{-3}$, while the surges had bulk densities in the range of $1700-2100 \mathrm{~kg} \mathrm{~m}^{-3}$. This led us to use high sediment concentration values by volume for our modeling scenarios that ranged between 0.55 for surges and 0.01 for extremely low inter-surge flows (Fig. 2).

The two-dimensional debris-flow simulations use the September 2009 debris flow data as it occurred closest to the time that the Airborne Laser Scanning (ALS) data were collected in 2008. The debris flow hydrography is routed across two 3m DEM generated from the original $1 \mathrm{~m}$ data collected via ALS techniques. The first model simulation incorporates the excavated channel and is used to corroborate the Flo-2D model by comparing the flow volume to the fan with the actually volume calculated from the TLS data in the field. A second DEM has the channel removed via converting the original DEM to points, clipping out the channel points, and interpolating the point cloud back to a $1 \mathrm{~m}$ DEM and then converting the $1 \mathrm{~m}$ DEM to a $3 \mathrm{~m}$ DEM. Both models used the same preset viscosity and yield stress values specified for the Glenwood 3 debris flow in the Flo-2D reference manual as simulations based on these flow properties closely approximated the September 2009 debris flow at Chalk Cliffs. Three modeled debris flows were run in the no channel scenario, and in each case a new DEM with the added debris flow deposition from the previous flow(s) was used in the modeling experiment. In all cases, the models performed within the specified parameters tested by Flo-2D (i.e., volume conservation, numerical stability, velocities, and n-values), and the debris-flow volume arriving at the embryonic fan surface showed excellent relationships with the actual field surveyed volume (as described below).

\subsection{Geomorphic change detection}


The DEMs of Difference (DOD: DEM after the debris flow minus DTM prior to debris flow) are created using the raster calculator in ArcGIS (Wheaton et al., 2010; Staley et al., 2014; Wester et al., 2014). Differencing the DEMs produced a map of elevation changes on the embryonic fan. Topographic differences aid in the calculation of volumetric budgets of erosion and deposition (Wheaton et al., 2010). The following equation was used to extract the volume changes:

$$
V=A \sum_{i=1}^{N} \Delta Z_{i}
$$

where $\mathrm{V}=$ volumetric change $\left(\mathrm{m}^{3}\right), \mathrm{A}=$ area of analysis $\left(\mathrm{m}^{2}\right), \mathrm{N}=$ number of pixels, and $\Delta Z_{i}=$ change in elevation at the pixel $(\mathrm{m})$.

Total sediment contributions to Chalk Creek from the debris flows is investigated by measuring erosion from the embryonic fan toe and sediment plug in the channel immediately after the debris flow. Each measured debris flow temporarily plugged the channel. Water ponded behind the temporary dam associated with the channel plugging. The channel plug was eventually overtopped and eroded via headward incision and/or downcutting. Erosion of debris-flow deposits plugging in the channel is calculated from extrapolating a reference plane from the fan toe to known indicators of sediment deposition (in many cases, mud deposits on trees on the opposite bank or new material added to the bank opposite the fan). A volume to the water surface is measured (the scanner did not penetrate the water to the bed of the stream) and therefore represents a minima value. Fan toe erosion is calculated by clipping the point cloud data to the extent the fan toe built outward or eroded backward between the debris flows. The clipped point clouds are converted to mesh surfaces. A volume is calculated from the water surface 
slope at the time of the scans, which again represents a minima value of material eroded or added. Leica's Cyclone software is used in both cases to determine these volume measures.

\section{Results}

\subsection{Channelization and telescopic behavior}

The debris flow-simulation volume matched well with the observed volume from our TLS surveys (model volume $=327 \mathrm{~m}^{3}$ and TLS survey volume $=338 \mathrm{~m}^{3}$ ). The debris-flow deposition (plug) in Chalk Creek occurred perpendicular to the feeder channel, which is approximately the same location evidenced in the field. However, the debris flow was not constrained to the southern portion of the embryonic alluvial fan (as was found from TLS data analyses described in the geomorphic change section), but rather spread more evenly across the embryonic fan surface and at thinner depths (Fig. 3A). We attributed the spread to the use of the $3 \mathrm{~m}$ DEM and the lack of detailed topography on the embryonic fan surface associated with this resolution DEM (Fig. 3). Another source of corroborating evidence for the accuracy of the two-dimensional models is the high deposition rates on the upper portion of the channelized stream and along the channelized stream just upstream from where the channel crosses CCR162 (Fig. 3). Both locations represent velocity decreases, which likely aided in sediment deposition (Fig. 3B), and both depositional areas were noted in the field after the debris flow (Fig. 4). The channel prior to crossing CCR162 was particularly low gradient.

Removal of the channelized portion of stream on the bajada produced an immediate shift in the locus of deposition and the runout distance (Fig. 5). A lack of flow constriction led to the debris flows spreading laterally. The simulated debris flows take a path toward a local camp (a series of buildings with numerous housing, meeting, and 
storage facilities) located on the north side of the bajada (Figs. 1 and 5). While the debris flows do not reach the buildings, the simulated debris flows were conducted using data gathered from volumetrically the smallest of the debris flows recorded during this study. Simulated debris flows do not display the same runout distances identified with the channelized flows. A majority of the debris flows extend only to CCR162. Clear evidence from all three debris flow simulations show the debris flows do not connect with the embryonic fan. Telescopic development of the alluvial fan ceases upon removal of the human built channel under the modeled scenario.

\subsection{Embryonic fan development}

Deposition dominated each of the five debris flows on the embryonic fan surface (not including the short term storage and then erosion in the fan toe and channel plug as discussed later). Surficial deposition ranged from $81.0 \%$ to $97.8 \%$ of the total detectable geomorphic change to the alluvial fan surface (Fig. 6). Maximum heights of deposition range from $0.75 \mathrm{~m}$ (June 2010) to $2.05 \mathrm{~m}$ (July 2011). Geomorphic change is detected predominantly on the southern side of the embryonic fan. Initially, deposition on the southern portion of the embryonic fan is associated with the debris flows spreading as they overtop the shallow channel on the embryonic fan surface (Fig. 7A). A new alluvial fan segment built on the southern side of the embryonic fan in response to a portion of the debris flow shifting back to an older flow path (Fig. 7B). The shift occurred along a steeper gradient of an older flow path. This flow pathway had been previously cut off by a levee just down from CCR162, which was built to constrict the flow to the channelized portion of the feeder to the embryonic fan (Fig. 8). The shift to this older flow pathway is also evident in the two-dimensional debris flow simulations, as the flows ran up against this levee (Fig. 3). During the final debris flow, the channelized portion of the stream is 
reoccupied and a shift in the locus of deposition occurred in the direction of the northern portion of the embryonic fan (Fig. 7C). Minor shifts in deposition to the northern portion of the fan are also present to a lesser extent during the third and fourth debris flows. The lead author has revisited the sight in 2012 and flows had continued to deposit to the northern portion of the fan. This pattern is also evident in the most recent imagery from Google Earth (June, 2013), where a new active channel and alluvial fan toe deposition in the northern portion of the embryonic fan (Fig. 9).

Significant geomorphic changes are evident in the broad two-dimensional form of the embryonic fan (Fig. 9A). These changes predominantly reflect the addition of new fan materials and losses of material along the embryonic fan toe from erosion associated with Chalk Creek channel changes. The debris flows had the ability to runout the entire length of the embryonic fan and plug Chalk Creek for short periods of time (on the order of hours to days). Chalk Creek ponded behind the channel plugs and then would overtop the deposits and excavate the channel plug materials to reopen the Chalk Creek channel. The amount of material eroded from the channel plug ranged from a low of $125.6 \mathrm{~m}^{3}$ to a high of $915.0 \mathrm{~m}^{3}$ (Table 3). Continuous bank erosion along Chalk Creek led to fan toe erosion subsequent to the removal of the channel plugs. Embryonic fan toe erosion varied from 0 to $1085.3 \mathrm{~m}^{3}$ (Table 3). Geomorphic changes along the embryonic fan margins, an area of little accommodation space, are much higher than those found on the fan surface (Fig. 10). Channelization of the debris flows has contributed a much larger portion of the sediment load being delivered to Chalk Creek despite the sediment storage on the embryonic alluvial fan (Fig. 10).

\section{Discussion}


Debris flow channelization across the Holocene bajada promoted telescopic development of the alluvial fan emanating from the Chalk Creek Valley Natural Debris Flow Laboratory. Our two-dimensional modeling simulations show under channelized conditions that debris flows remain constricted permitting them to runout to and deposit on the embryonic fan as well as into Chalk Creek. Several studies have shown debris flow constriction promotes debris flow propagation, provided the debris flow does not overtop the flow constriction (Hooke, 1967; Hungr et al., 1987; Whipple and Dunne, 1992; Iverson, 2014). Our analyses indicate the maintenance of the channelized portion of the fan will continue the process of telescopic fan evolution. Our results also highlight the need for a deeply incised channel to maintain the telescopic development of the embryonic fans, which was previously postulated by Bull (1977).

Broader implications from our findings can be drawn despite the small sample size. Under natural conditions where debris flows are consistently supplying material to an alluvial fan, the presence of a deeply incised channel through the fan apex might be a precursor to the development of an embryonic fan and lead to the telescoping nature of alluvial fans in other locations. Progradation of an alluvial fan via this method in other locations would seem to be constrained to a large extent by amount of accommodation space available (as discussed later) rather then the incised channel morphometry. Channelization of the bajada fan in our study exhibited a largely rectilinear morphometry with only minor portions of the channel exhibiting terraces; other studies have found telescoping development on alluvial fans where incised channels possess extensive inset terraces (Colombo, 2005; Sancho et al., 2008). In either case, flow confinement is present and assists in developing the embryonic fan or new fan segment in front of the older segment. Our example also shows the development and maintenance of the embryonic fan and telescopic fan behavior can occur in the absence of tectonic activity. 
Secondary processes and forms have the potential to interfere with the maintenance of the incised channel. In turn, this would reduce the potential of the channel to contain debris flows and ultimately the perpetuation of the telescoping nature of the fan and embryonic fan development. These include items such as the periodic aggradation of the channel via debris flows or bank collapse that would reduce the cross-sectional area of the channel, channel plugging by vegetation or coarse particles, or an avulsion near the apex or along the length of the channelized flow.

Telescopic fan development at our study site will persist as long as channelized flows are present based on our findings and observations. However, the size of the fan is limited by the lack of accommodation space within the Chalk Creek valley and by the continued erosion of the alluvial fan toe by Chalk Creek. Embryonic fan toe erosion is highly variable and dependent on the migration of the Chalk Creek channel into the embryonic fan toe. Our field observations indicate that the changes in the location of Chalk Creek coincide with the addition of debris flow material to the channel. Chalk Creek is a single-thread channel above the fan, but at the embryonic fan stream flow constricts and then bifurcates or sometimes takes on a distributary nature below the constriction. The flow constriction is a fairly consistent location of fan toe erosion. The northern portion of the embryonic fan erodes in response to a large portion of higher flows splitting and cutting into the northern portion embryonic fan toe. The bifurcation or distributary nature of Chalk Creek is associated with the large sediment deposits in the stream that are eroded material from the embryonic fan toe and the channel plug. The excess sediment added from the erosion of the debris flow material likely leads to the Chalk Creek channel shifts below the flow constriction, and these channel shifts ultimately control a large portion of the embryonic fan toe erosion. The continuous erosion by the Chalk Creek channel migration over time and the lack of further accommodation would seem to limit telescopic expansion of the embryonic fan and 
further developments of a new fan segment in front of the existing embryonic fan. Chalk Creek valley expansion would seem to be the only possible way to produce more accommodation space, but this does not seem likely as the deposits and bedrock confining the valley on its eastern side are not eroding rapidly, despite the flow constriction along Chalk Creek.

The removal of the human-modified channel from the bajada surface in our terrain model led to a shift in loci of deposition from the embryonic fan to middle and distal portions of the Holocene bajada. Flows spread on the fan surface and the runout distances decrease, even in the absence of vegetation on the DEM used in the modeling scenarios. While not part of the current modeling experiments, we hypothesize the runout distances would decrease for a comparable flow, should we account for the presence of vegetation in the models. A portion of the modeled debris flow runouts did travel in the direction of the dwellings on the northern side of the bajada. The simulated debris flow was the smallest of the recorded debris flows in terms of volume we measured during our period of study; so in the absence of channelized flow, the buildings and human life are at risk in the event of larger debris flows. This supposition is based on the debris flows maintaining or slightly deviating along the modeled flow pathways.

Another important aspect associated with debris flow risks for structures on the bajada would be concerns with the temporary nature of shallow, entrenched channels. Numerous studies have indicated shallow, entrenched channels do not persist for long periods of time and have shown that flows often overtop an aggrading entrenched channel (Bull, 1977). The anthropogenically modified channel can receive significant debris-flow deposition during a single event. Should the channel fill and a subsequent debris-flow surge or debris-flow event occur prior to excavating the channel, a strong potential exists for overtopping of the banks and thereby, increasing the risk of debris- 
flow inundation within the built environments on the northern portion of the bajada, as evidenced in our modeling experiments and supported through our field observations along the channel.

Debris-flow deposition was largely responsible for the embryonic evolution over the period of study. The first four debris flows largely deposited material on southern portion of the embryonic fan or increased the embryonic fan width by adding a new fan segment along an older drainage pathway adjacent to the human-built channel. Regardless of the pathway, the early trend in fan development is aggradation of the southern portion of the fan, which increases the fan height in this vicinity. The fourth debris flow and to a lesser extent the third debris flow, while largely contributing material to the southern portion of the embryonic fan, begin to deposit material on the northern portion of the embryonic fan. This trend continues and increases during the fifth debris flow with more material being deposited on the northern portion of the embryonic fan. The pattern is similar to those described in Hooke (1967) and Hooke and Rohrer (1979). These authors dub this as a high-low effect, whereby aggradation occurs on a portion of the alluvial fan and then shifts to a lower location along a pathway possessing a higher energy gradient.

The current project did not have funding to continue the fan monitoring via TLS, but a visit to the site in 2013 and recent aerial imagery have shown significant deposition has now occurred on the northern portion of the embryonic fan (Fig. 9). The rapid shifts in deposition associated with the high-low effect indicate the fan surface is evolving rapidly over a period of 5-10 years. Similar rapid changes to alluvial fan surfaces have been shown to occur in other locations (Colombera and Bersezio, 2011), but unlike these other locations the changes are not associated with broader regional or tectonic controls. Rather, we hypothesize embryonic fan development is associated with changing loci of deposition that are a function of the internal variations in embryonic fan 
topography and in the amount of sediment delivered to the embryonic fan. Shifts in the loci of deposition on an embryonic fan begin to occur when there are significantly larger debris flow volumes being brought to the embryonic fan. A doubling of the sediment load delivered to the embryonic fan from second to third and second to fourth debris flows occur at the time these shifts begin (Fig. 10). The larger volumes likely overtop low relief levees along the shallow, incised, embryonic fan channel and permit flows to move from the southern to the northern portion of the alluvial fan, which was topographically much lower than the southern portion of the embryonic fan.

Debris flow sediment contributions are not only important to the evolution of the embryonic fan and maintenance of the broader telescopic fan development, but also have significant implications for the adjacent Chalk Creek riverine ecosystem. The channelization of flows across the fan in the bajada has led to unprecedented amounts of sedimentation in and around the embryonic fan. Prior to the formation of the embryonic fan, accumulation rates at the toe of the bajada (prior to channelization) are on the order of $0.1 \mathrm{~cm} / \mathrm{yr}$, whereas active accumulation rates currently on the embryonic fan on the order of $10 \mathrm{~cm} / \mathrm{yr}$ (Coe et al., 2010). Current embryonic fan accumulation rates are on the order of what would be expected at the bajada apex prior to establishment of the human-built channel (Coe, personal communication and unpublished results). Our volumetric measures of the five debris flows (Fig. 10) provide clear evidence to suggest Chalk Creek is receiving a much larger amount of sediment than the normal background levels of sediment in this vicinity. A majority of the sediment being delivered is not stored on the embryonic fan but is directly input to Chalk Creek. $A$ clear trade-off is present here at this site. While channelization of flows is protecting built environments on the bajada, the end result is a significant portion of the channelized sediment is being delivered directly to Chalk Creek as excess sediment. Chalk Creek erodes the debris flow deposits rapidly; within days to weeks a vast majority of the debris 
flow sediment is incorporated as bedload and suspended load. However, sediment loads are significantly increased in Chalk Creek and these sediment loads have the potential to impact the physical and biological integrity of the stream (Graf, 2001) and can also impact infrastructures placed in and along the stream. Any future attempts of channelizing flows across the bajada surface in this and other similar geomorphic settings should consider a balance between engineered solutions to protect society and protecting the structural and functional components of riverine ecosystems.

\section{Conclusion}

The high frequency of debris flows at the Chalk Creek Valley Natural Debris Flow Laboratory has provided an excellent opportunity to investigate the telescoping nature of alluvial fan development. Debris-flow constriction by human-induced channelization of the Holocene bajada has increased runout distances and promoted the development of a telescopic fan. The embryonic fan in the new telescoping segment is small in comparison to the alluvial fan in the bajada complex because of the lack of accommodation space and erosion of the embryonic fan toe by the adjacent Chalk Creek. The size of the embryonic fan is not likely to increase without a corresponding increase in the accommodation space, which would only be possible with an eastward shift of the Chalk Creek channel. This scenario is unlikely because of the thick deposits and bedrock forming the eastern bank of Chalk Creek, and therefore further fan segmentation and telescopic expansion is unlikely.

Our two-dimensional modeling experiments show debris flows entering the bajada in the absence of human-induced channelization shift the loci of deposition, spread, and show evidence of decreased runout distances. Debris-flow spreading and shorter runout distances lead to disconnectivity between the feeder channel and the 
embryonic fan. Over several simulated flows, the telescoping nature of the fan and further development of the embryonic fan shut down. Removal of the embryonic fan, if this scenario were to be brought about, would be highly likely. Chalk Creek possesses the energy to erode the materials stored in the fan over a period of time. The shift in the locus of deposition also puts houses and other infrastructure at risk of debris-flow inundation and damage. Modeled debris flows take a path in the direction of a local camp (numerous buildings) located on the northern portion of the bajada. Building in the northern portion of the bajada have the potential to be inundated should the channel be removed. Our modeling experiments use the smallest debris-flow volume recorded at the embryonic fan during our study period and the likelihood of a larger debris flow reaching the camp is high given the topographic controls on the bajada surface.

We have also leveraged the ability of TLS to collect spatially and temporally highresolution topographic data to detect elevation changes and to produce detailed morphometric sediment budgets for the embryonic fan. The resulting data sets provide insights into the evolution of the fan in relation to a human-induced telescoping alluvial fan system. The debris flows measured at the embryonic fan were predominantly depositional as $80 \%$ to $98 \%$ of the change detected on the embryonic fan surface was via deposition. Deposition on the embryonic fan was constrained to the fan's southern portion and ranged between a maximum height of 0.75 and $2.05 \mathrm{~m}$. The last three debris flows also started to deposit material on the northern portion of the embryonic fan and continued field visits and aerial photography indicate this pattern continued to present with a large deposit noticeable on the northern side of the embryonic fan in the most recent aerial imagery. The shift in deposition from the southern to northern portion of the embryonic fan is similar to the high-low effect noted by Hooke (1967) and Hooke and Rohrer (1979) in their experimental models and field observations. Debris flows that built the southern portion of the embryonic fan are creating a topographically higher surface. 
A gradual shift in the deposition from the higher portion of the fan to the lower portion occurred as debris flows overtopped the low incised channel and low levees at the fan apex.

While the embryonic fan was actively building vertically and laterally during the period of study, deposits in the distal portions of the embryonic fan were largely eroded. Distal portions of the embryonic fan were very dynamic as a result of the plug erosion and fan toe erosion. Debris-flow deposits plugged the channel and were eroded as the stream overtopped the plug and incised through the deposits. Much of the material was incorporated into the channel as bedload and suspended sediments within days to weeks of the debris flow occurrence. An assessment of the total volume of material stored on the embryonic fan versus material eroded into the channel showed that a much higher portion of debris flow deposition was incorporated into Chalk Creek than was stored in the embryonic fan. Our example shows that when considering engineered solutions to reduce debris-flow risk to human inhabitants and built infrastructure, both the natural and built environments must be considered. A vast majority of the sediment from the channelized flows is being dumped as excess sediment into Chalk Creek. Excess sediment can significantly modify the physical and biological structures and functions in streams like Chalk Creek and can also impact built structures (i.e., irrigation, bridges, dams, etc.) during floods. Channelization of the debris flows has obviously protected the built environments on the bajada. However, repercussions from this management scheme are evident. A major portion of the debris transported along the channelized bajada is being received as excess sediment in Chalk Creek.

The study also presents some broader reaching observations with regard to the behavior of alluvial fans that are developing in a telescoping nature. The importance of flow constriction/confinement is a particularly significant factor in the propagation of debris flows and subsequent progradation by alluvial fan. A relatively rectilinear channel 
is present at Chalk Cliffs, but other locations with telescopic alluvial fan development show extensive inset terraces in incised channels (Colombo, 2005; Sancho et al., 2008). This would suggest that the morphometry of the feeder channel is not as important as the actual flow confinement itself. The study has also shown that telescopic development of an alluvial fan can take place in the absence of tectonics or climate change. Alluvial fan entrenchment in the absence of broader forcing factors has been shown in field and modeling experiments associated with alluvial fan dominated by fluvially processes (Clarke et al., 2008, 2010; Nicholas et al., 2009). The current study provides strong evidence for similar responses in debris-flow-dominated alluvial fans as well as the evidence that alluvial fans can prograde in the absence of these broader forcing factors. 


\section{Acknowledgements}

The authors would like to thank the following researchers with assistance in collecting field data or acquiring flow data: Dennis Staley, Jason Kean, Jeff Coe from the USGS Landslide Hazards Program; Scott McCoy at the University of Nevada, Reno. Kathryn Reavis and Thad Wester assisted in the acquisition of the 2009 and 2010 TLS data. This material is based upon work supported by the National Science Foundation (NSF) under Grant No. 0239749, entitled "CAREER: Alluvial Fan Form Quantification to Advance Geographic Science and Education" and Grant No. 0934131, entitled "Geomorphic Connectivity in a Recently Burned Watershed". Disclaimer: Any opinions, findings, conclusions, or recommendations expressed in this material are those of the authors and do not necessarily reflect the views of the NSF or any of the reviewers of this material. Further funding was supplied from a USGS Senior Scientist in Residences Award received by Thad Wasklewicz in spring of 2009 (Dennis Staley was PI on this Award) and from the East Carolina University Office of Research and Graduate Studies' Research Development Award (RDA) Program. 


\section{REFERENCES}

Beaty, C.B., 1963. Origin of alluvial fans, White Mountains, California and Nevada. Annals of the Association of American Geographers 53, 516-35.

Berger, C., McArdell, B.W., Schlunegger, F., 2011. Direct measurement of channel erosion by debris flows, Illgraben, Switzerland. Journal of Geophysical Research, 116, F01002.

Blair, T.C., McPherson, J.G., 1994. Alluvial fans and their natural distinction from rivers based on morphology, hydraulic processes, sedimentary processes, and facies assemblages: Journal of Sedimentary Research, A64, 450-489.

Blair, T.C., McPherson, J.G., 2009. Processes and forms of alluvial fans. In: Parsons, A. J. and Abrahams, A.D. (eds) Geomorphology of desert environments. New York: Springer, pp. 413-467.

Blissenbach, E., 1954. Geology and alluvial fans in semi-arid regions. Bulletin of the Geological Society of America 65, 175-90.

Bovis, M.J. and Dagg, B.R., 1992. Debris flow triggering by impulsive loading: mechanical modeling and case studies. Canadian Geotechnical Journal, 29, 345352.

Bryant, M., Falk, P., Paola, C., 1995. Experimental study of avulsion frequency and rate of deposition. Geology 23, 365-368.

Bull, W.B., 1977. The alluvial fan environment. Progress in Physical Geography 1, 222270.

Calvache, M.L., Viseras, C., Fernández, J., 1997. Controls on fan development — evidence from fan morphometry and sedimentology; Sierra Nevada, SE Spain Geomorphology 21, 69-84.

Cannon, S.H., Gartner, J.E., Parrett, C., Parise, M., 2003. Wildfire-related debris-flow generation through episodic progressive sediment-bulking processes, western 
USA. In: Rickenmann, D., Chen, C.L., (Eds.), Debris-flow hazards mitigation mechanics, prediction and assessment, proceedings of the Third International Conference on Debris-Flow Hazards Mitigation, Davos, Switzerland, 10-12 September 2003. A.A. Balkema, Rotterdam, pp. 71-82.

Clarke, L., Quine, T., Nicholas, A., 2008. An evaluation of the role of physical models in exploring form process feedbacks in alluvial fans. Sediment Dynamics in Changing Environments, IAHS Publication 325, 175-183.

Clarke, L., Quine, T.A., Nicholas, A., 2010. An experimental investigation of autogenic behaviour during alluvial fan evolution. Geomorphology 115, 278-285.

Coe, J.A., Kinner, D.A., Godt, J.W., 2008. Initiation conditions for debris flows generated by runoff at Chalk Cliffs, central Colorado. Geomorphology 96, 270-297.

Coe, J.A., Kean, J.W., McCoy, S.W., Staley, D.M., Wasklewicz, T.A., 2010. Chalk Creek Valley: Colorado's natural debris-fl ow laboratory, In: Morgan, L.A., and Quane, S.L., (Eds.), Through the Generations: Geologic and Anthropogenic Field Excursions in the Rocky Mountains from Modern to Ancient: Geological Society of America Field Guide 18, pp. 95-117.

Colombera, L., Bersezio R., 2011. Impact of the magnitude and frequency of debris-flow events on the evolution of an alpine alluvial fan during the last two centuries: responses to natural and anthropogenic controls. Earth Surface Processes and Landforms 36, 1632-1646.

Colombo, F., 2005. Quaternary telescopic-like alluvial fans, Andean Ranges, Argentina. In: Harvey, A. M., Mather, A. E. and Stokes, M. (Edss) Alluvial fans: geomorphology, sedimentology, dynamics. London: Geological Society Special Publications 251, pp. 69-84. 
Costa, J.E., 1984. Physical geomorphology of debris flows. In: Costa, J.E., Fleisher, P.J. (Eds.), Developments and Applications of Geomorphology. Springer-Verlag, Berlin, pp. 268-317.

Coulthard, T.J., Van De Wiel, M.J., 2007. Quantifying fluvial non linearity and finding self organized criticality: Insights from simulations of river basin evolution. Geomorphology 91, 216-235.

Coulthard, T.J., Macklin, M.G., Kirkby, M.J., 2002. A cellular model of holocene upland river basin and alluvial fan evolution. Earth Surface Processes and Landforms 27, 269-288.Davies, T.R., Korup, O., 2007. Persistent alluvial fanhead trenching resulting from large, infrequent sediment inputs. Earth Surface Processes and Landforms 32, 725-742.

Dühnforth, M., Densmore, A., Ivy-Ochs, S., Allen, P., 2008. Controls on sediment evacuation from glacially modified and unmodified catchments in the eastern Sierra Nevada, California. Earth Surface Processes and Landforms 33, 16021613.

Ferrier, G., Pope, R.J., 2012. Quantitative mapping of alluvial fan evolution using ground-based reflectance spectroscopy. Geomorphology 175, 14-24.

Field, J., 2001. Channel avulsion on alluvial fans in southern Arizona. Geomorphology $37,93-104$.

Franke, D., Hornung, J., Hinderer, M., 2015. A combined study of radar facies, lithofacies and three-dimensional architecture of an alpine alluvial fan (Illgraben fan, Switzerland). Sedimentology, 62, 57-86.

Frankel, K.L., Dolan, J.F., 2007. Characterizing arid region alluvial fan roughness with airbourne laser swath mapping digital topographic data. Journal of Geophysical Research 112, pp. F02025. 
Fuller, I.C., Marden, M., 2011. Slope-channel coupling in steepland terrain: A fieldbased conceptual model from the Tarndale gully and fan, Waipaoa catchment, New Zealand. Geomorphology 128, 105-115.

Gabet, E.J., Bookter, A., 2008. A morphometric analysis of gullies scoured by post-fire progressively-bulked debris flows in southwest Montana, USA. Geomorphology, 96, 298-309.

Graf, W.L., 1975. The impact of suburbanization on fluvial geomorphology. Water Resources Research 11, 690-692.

Graf, W.L., 1979. Mining and channel response. Annals of the Association of American Geographers 69, 262-275.

Graf, W.L., 1985. Mercury transport in stream sediments of the Colorado Plateau. Annals of the Association of American Geographers 75, 552-565.

Graf, W.L., 1996. Transport and deposition of plutonium-contaminated sediments by fluvial processes, Los Alamos Canyon, New Mexico. Geological Society of America Bulletin 108, 1342-1355.

Graf, W.L., 2000. Locational probability for a dammed, urbanizing stream: Salt River, Arizona, USA. Environmental Management 25, 321-335.

Graf, W.L., 2001. Damage control: restoring the physical integrity of America's rivers. Annals of the Association of American Geographers 91, 1-27.

Graf, W.L., 2005. Geomorphology and American dams: the scientific, social, and economic context. Geomorphology 71, 3-26.

Graf, W.L., 2006. Downstream hydrologic and geomorphic effects of large dams on American rivers. Geomorphology 79, 336-360.

Harvey, A.M., 1978. Dissected alluvial fans in southeast Spain. Catena 5, 177-211.

Harvey, A.M., 1984. Aggradation and dissection sequences on Spanish alluvial fans: influence on morphological development. Catena 11, 289-304. 
Harvey, A.M., 2002. The role of base-level change on the dissection of alluvial fans: case studies from southeast Spain and Nevada. Geomorphology 45, 67-87. Harvey, A.M., 2005. Differential effects of base-level, tectonic setting and climatic change on Quaternary alluvial fans in the northern Great Basin, Nevada, USA. In: Harvey AM, Mather AE, Stokes M (Eds.). Alluvial Fans: Geomorphology, Sedimentology, Dynamics, Geological Society: London; Special Publication 251, 117-131.

Hashimoto, A., Oguchi, T., Hayakawa, Y., Lin, Z., Saito, K., Wasklewicz, T., 2008. GIS analysis of depositional slope change at alluvial-fan toes in Japan and the American Southwest. Geomorphology 100, 120-130.

Hooke, R.L., 1967. Processes on arid-region alluvial fans. Journal of Geology 75, 438460.

Hooke, R.L., 1987. Mass movement in semi-arid environments and the morphology of alluvial fans. In Anderson, M.G., Richards, K.S., (Eds.)., Slope stability, New York, Wiley, pp. 505-529.

Hooke, R.L., Dorn, R.I., 1992. Segmentation of alluvial fans in Death Valley, California: new insights from surface exposure dating and laboratory modeling. Earth Surface Processes and Landforms 17, 557-574

Hooke, R.L., Rohrer, W.L., 1979. Geometry of alluvial fans: effect on discharge and sediment size. Earth Surface Processes and Landforms 4, 147-166.

Hungr, O., 2000. Analysis of debris flow surges using the theory of uniformly progressive flow. Earth Surface Processes and Landforms, 25, 483-495.

Hungr, O., Morgan, G.C., VanDine, D.F., Lister, D.R., 1987. Debris flow defenses in British Columbia. Reviews in Engineering Geology 7, 201-222.

Hürlimann, M., Rickenmann, D., Graf. C., 2003. Field and monitoring data of debris-flow events in the Swiss Alps. Canadian Geotechnical Journal, 40, 161-175. 
Imaizumi, F., Tsuchiya, S., Ohsaka, O., 2005. Behaviour of debris flows located in a mountainous torrent on the Ohya landslide, Japan. Canadian Geotechnical Journal, 42, 919-931.

Iverson, R.M., 1997. Physics of debris flows. Reviews of Geophysics, 35, 245-296.

Iverson, R.M., 2014. Debris flows: behaviour and hazard assessment. Geology Today 30, 15-20.

Iverson, R.M., 2003. The debris-flow rheology myth. Debris-flow hazards mitigation: mechanics, prediction, and assessment 1, 303-314.

Iverson, R.M., Reid, M.E., LaHusen, R.G., 1997. Debris-flow moblization from landslides. Annual Review of Earth and Planetary Sciences, 25, 85-138.

Iverson, R.M., Reid, M.E., Logan, M., LaHusen, R.G., Godt, J.W., Griswold, J.P., 2011. Positive feedback and momentum growth during debris-flow entrainment of wet bed sediment. Nature Geoscience, 4, 116-121.

Johnson, A.M., 1970. Physical processes in geology. San Francisco: Freeman, Cooper. Johnson, A.M., Rodine, J.R., 1984. Debris flow. In: D. Brundsen and D.B. Prior (Eds.), Slope Instability. John Wiley and Sons, New York, pp. 257-361.

Major, J.J., Iverson, R.M., 1999. Debris-flow deposition: Effects of pore-fluid pressure and friction concentrated at flow margins. Geological Society of America Bulletin, $111,1424-34$

McCoy, S. W., Kean, J.W., Coe, J.A., Staley, D.M., Wasklewicz, T.A., Tucker, G.E., 2010. Evolution of a natural debris flow: in situ measurements of flow dynamics, video imagery, and terrestrial laser scanning. Geology 38, 735-738.

McCoy, S., Coe, J., Kean, J., Tucker, G., Staley, D., and Wasklewicz, T., 2011. Observations of debris flows at Chalk Cliffs, Colorado, USA: part 1, in-situ measurements of flow dynamics, tracer particle movement and video imagery from the summer of 2009. In: Genevois, R., Hamilton, D. L. and Prestininzi, A. 
(Eds.) Proceedings of the 5th International Conference on Debris Flow Hazards Mitigation, Mechanics, Prediction and Assessment, Padua, Italy, June 14-17, 2011. Rome, Italy: Italian Journal of Engineering Geology and Environment and Casa Editrice Universita La Sapienza, pp. 715-724.

McCoy, S.W., Kean, J.W., Coe, J.A., Tucker, G.E., Staley, D.M., Wasklewicz, T.A., 2012. Sediment entrainment by debris flows: In situ measurements from the headwaters of a steep catchment. Journal of Geophysical Research: Earth Surface 117, F3.

Mills, H.H., 2000. Controls on form, process, and sedimentology of alluvial fans in the Central and Southern Appalachians, Southeastern U.S.A. Southeastern Geology 39, 281-313.

Nicholas, A.P., Quine, T.A., 2007a. Modelling alluvial landform change in the absence of external environmental forcing. Geology $35,527-530$.

Nicholas, A.P., Quine, T.A., 2007b. Crossing the divide: Representation of channels and processes in reduced-complexity river models at reach and landscape scales. Geomorphology 90, 318-339.

Nicholas, A.P., Clarke, L., Quine, T.A., 2009. A numerical modelling and experimental study of flow width dynamics on alluvial fans. Earth Surface Processes and Landforms 34, 1985-1993.

O'Brien, J.S., Julien, P.Y., 1988. Laboratory analysis of mudflow properties. Journal of Hydraulic Engineering 114, 877-887.

O'Brien, J.S., Julien, P.Y., Fullerton, W.T., 1993. Two-dimensional water flood and mudflow simulation. Journal of Hydraulic Engineering 119, 244-261.

Ohmori, H., Shimazu, H., 1994. Distribution of hazard types in a drainage basin and its relation to geomorphological setting. Geomorphology, 10, 95-106. 
Okuda, S., Suwa, H., 1981. Topographical change caused by debris flow in Kamikamihori Valley, northern Japanese Alps. Transactions - Japanese Geomorphological Union, 2, 343-352.

Okuda S., Suwa H., Okunishi K., Yokoyama K, Ogawa K., Hmana H., Tanaka S., 1980. Synthetic observation on debris flow, Part 6: Observation at Kamikamihorizawa valley of Mt. Yakedake in 1979. Annuals, DPRI, 23B-1, 357-394 (in Japanese).

Pepin, E., Carretier, S., Hérail, G., 2010. Erosion dynamics modelling in a coupled catchment-fan system with constant external forcing. Geomorphology 122, 7890.

Phillips, C.J., Davies, T.R., 1991. Determining rheological parameters of debris flow material. Geomorphology 4, 101-110.

Pope, R.J.J., Wilkinson, K., Skourtsos, E., Triantaphyllou, M., Ferrier, G., 2008. Clarifying stages of alluvial fan evolution along the Sfakian piedmont, southern Crete: new evidence from analysis of post-incisive soils and OSL dating. Geomorphology 94, 206-225.

Price, S., Higham, T., Nixon, L., Moody, J., 2002. Relative sea-level changes in Crete: reassessment of radiocarbon dates from Sphakia and west Crete. The Annual of the British School at Athens, 97, 171-200.

Ritter, J.B., Miller, J.R., Husek-Wulforst, J., 2000. Environmental controls on the evolution of alluvial fans in the Buena Vista Valley, North Central Nevada, during late Quaternary time. Geomorphology, 36: 63-87.

Robustelli, G., Muto, F., Scarciglia, F., Spina, V., Critelli, S., 2005. Eustatic and tectonic control on Late Quaternary alluvial fans along the Tyrrhenian Sea coast of Calabria (south Italy). Quaternary Science Reviews 24, 2101-2119.

Sancho, C., Peña, J.L., Rivelli, F., Rhodes, E., Muñoz, A., 2008. Geomorphological evolution of the Tilcara alluvial fan (Jujuy Province, NW Argentina): Tectonic 
implications and palaeoenvironmental considerations. Journal of South American Earth Sciences 26, 68-77.

Scheinert, C., Wasklewicz, T., Staley, D., 2012. Alluvial Fan Dynamics-Revisiting the Field. Geography Compass 6, 752-775.

Sosio, R., Crosta, G.B., Frattini, P., 2007. Field observations, rheological testing and numerical modelling of a debris-flow event. Earth Surface Processes and Landforms 32, 290-306.

Spelz, R.M., Fletcher, J.M., Owen, L.A., Caffee, M.W., 2008. Quaternary alluvial-fan development, climate and morphologic dating of fault scarps in Laguna Salada, Baja California, Mexico. Geomorphology 102, 578-594.

Staley, D.M., Wasklewicz, T.A., Blaszczynski, J.S., 2006. Surficial patterns of debris flow deposition on alluvial fans in Death Valley, CA using airborne laser swath mapping data. Geomorphology 74, 152-63.

Staley, D.M., Wasklewicz, T.A., Coe, J.A., Kean, J.W., McCoy, S.W., Tucker, G.E., 2011. Observations of debris flows at Chalk Cliffs, Colorado, USA: part 2, changes in surface morphometry from terrestrial laser scanning in the summer of 2009. In: Genevois, R., Hamilton, D. L. and Prestininzi, A. (Eds.) Proceedings of the 5th International Conference on Debris Flow Hazards Mitigation, Mechanics, Prediction and Assessment, Padua, Italy, June 14-17, 2011. Rome, Italy: Italian Journal of Engineering Geology and Environment and Casa Editrice Universita La Sapienza, pp. 759-768.

Staley, D., Wasklewicz, T., Kean, J., 2014. Characterizing the primary material sources and dominant erosional processes for post-fire debris-flow initiation in a headwater basin using multi-temporal terrestrial laser scanning data. Geomorphology 214, 324-338. 
Suwa, H., Okuda, S., 1983. Deposition of debris flows on a fan surface, Mt. Yakedake, Japan. Zeitschrift fur Geomorphologie Supplementbande 46, 79-101.

Takahashi, T., 1981. Debris flow, Annual Review of Fluid Mechanics, 13, 57-77.

Thomas, M.F., 2003. Late Quaternary sediment fluxes from tropical watersheds. Sedimentary Geology, 162: 63-81.

Tucker, G.E., Hancock, G.R., 2010. Modelling landscape evolution. Earth Surface Processes and Landforms 35, 28-50.

Viseras, C., Calvache, M.L., Soria, J.M., Fernández, J., 2003. Differential features of alluvial fans controlled by tectonic or eustatic accommodation space. Examples from the Betic Cordillera, Spain. Geomorphology 50, 181-202.

Volker, H.X., Wasklewicz, T.A., Ellis, M.A., 2007. Topographic fingerprint to distinguish Holocene alluvial fan formative processes. Geomorphology 88, 34-45.

Wasklewicz, T., Mihir, M., Whitworth, J., 2008. Surface variability of alluvial fans generated by disparate processes, Eastern Death Valley, CA. The Professional Geographer 60, 207-223.

Weissmann, G.S., Bennett, G.L., Lansdale, A.L., 2005. Factors controlling sequence development on Quaternary fluvial fans, San Joaquin Basin, California, USA. Special Publication-Geological Society of London 251, 169-186.

Wester, T., Wasklewicz, T., Staley, D., 2014. Functional and structural connectivity within a recently burned drainage basin. Geomorphology 206, 362-373.

Wheaton, J.M., Brasington, J., Darby, S.E., Sear, D., 2010. Accounting for uncertainty in DEMs from repeat topographic surveys: improved sediment budgets. Earth Surface Processes and Landforms 35, 136-156.

Whipple, K.X., Dunne, T., 1992. The influence of debris-flow rheology on fan morphology, Owens Valley, California. Geological Society of America Bulletin $104,887-900$. 
Zimmermann, M., 1991. Formation of debris flow cones: results from model tests.

Proceedings of the U.S.-Japan Symposium of Snow Avalanche, Landslide Debris-Flow Prediction and Control, pp. 463-470. 
Figure Captions

Fig. 1. A map of the Chalk Creek Valley Natural Debris Flow Laboratory and the telescoping alluvial fan. Slope $>45^{\circ}$ are near the top of the drainage basin represent exposed bedrock and slopes between 15 and $45^{\circ}$ represent stored colluvial material within the watershed. The lower station is where the debris flow stage data were collected to construct the debris flow hydrograph.

Fig. 2. The debris flow hydrograph used in the Flo-2D modeling and an associated TLS point cloud of the lower gauge at the Chalk Creek Valley Natural Debris Flow Laboratory. The cross section dimensions from the point cloud assisted in the development of debris flow discharge.

Fig. 3. Flo-2D debris flow simulations for the channelized bajada draped on a $1 \mathrm{~m}$ planimetric resolution hillshade map. (A) is the flow depth for the initial model run of the channelized debris flow. The flow deposition on the eastern side of the image is the embryonic fan location. (B) Presents the flow velocities along the channel.

Fig. 4. (A) Photo taken after the July 2010 debris flow at the bend below where the feeder channel debouches onto the fan surface showing terraces (likely from tailwater incision) cut into a thick layer of freshly deposited debris sediment. (B) Highlights deposition in the channel section above CCR162. Note levee of material inset within the channel on the right side of the image.

Fig. 5. Debris flow model with the channel removed from the bajada. The debris flow runout distance has decreased from the channelized flows. The flow has also spread laterally and has moved in the direction of the buildings on the northern portion of the bajada. The model is draped on a $1 \mathrm{~m}$ planimetric resolution hillshade map with the channel still present in the hillshade to use as a point of reference.

Fig. 6. Morphometric sediment budgets for each of the debris flows reaching the embryonic fan.

Fig. 7. DEM-of-difference surfaces for September 2009 (A), August 2010 (B), and the elevation change for the entire study period from July 2011 to May 2009 (C).

Fig. 8. Gradient starting above CCR162 along the channelized flow (blue) and an older channel from the bajada (green). Note the older channel is actually steeper (without the levee) for the first $60 \mathrm{~m}$ and is the path the debris flows would take without channelization. This is evident in the field and from the model simulations.

Fig. 9. (A) Map depicting variability of the embryonic fan perimeter to annual changes and individual debris flows over the period of study. (B) Google Earth Image of the embryonic fan from 10 June 2013 showing an active channel and recent deposition at the alluvial fan toe downstream on the northern side (right portion of the image).

Fig. 10. Debris flow deposition on the embryonic fan versus the amount of sediment deposited in and eroded by Chalk Creek. 
Table 1

A timeline of events covering the extent of the current study at Chalk Cliffs ${ }^{a}$

\begin{tabular}{|c|c|c|c|c|c|c|}
\hline $\begin{array}{c}\text { Date } \\
(m-d-y)\end{array}$ & Survey \# & Event & $\begin{array}{l}\text { Cum. Rain } \\
(\mathrm{mm})\end{array}$ & $\begin{array}{l}\text { Rain duration } \\
\qquad(\min )\end{array}$ & $\begin{array}{c}\text { Peak } \\
\text { Stage }(m) \\
\text { Upper } \\
\text { Station }\end{array}$ & $\begin{array}{c}\text { Peak } \\
\text { Stage }(\mathrm{m}) \\
\text { Middle Station }\end{array}$ \\
\hline 05-29-09 & S1 & Begin Season & No Rain & No Rain & No Flow & No Flow \\
\hline 06-02-09 & & Debris flow & 9.9 & 300 & 0.31 & 0.34 \\
\hline 08-03-09 & & Debris flow & 10.7 & 78 & 0.32 & 0.16 \\
\hline 09-06-09 & & Debris flow & 6.3 & 45 & 0.53 & 0.80 \\
\hline 09-15-09 & S2 & Debris flow & 24.6 & 115 & 1.10 & 0.45 \\
\hline $05-30-10$ & S3 & Begin Season & No Rain & No Rain & No Flow & No Flow \\
\hline $06-15-10$ & S4 & Debris flow & 25.0 & 720 & 0.88 & Not Available \\
\hline $07-09-10$ & S5 & Debris flow & 34.0 & 45 & 1.40 & 1.80 \\
\hline $08-20-10$ & S6 & Debris flow & Not Avail. & Not Avail. & Not Available & Not Available \\
\hline 6-28-11 & S7 & Debris flow & 19.0 & 45 & 1.20 & Not Available \\
\hline
\end{tabular}

${ }^{a}$ A scan was conducted at the beginning of each season and after each debris flow that made it to the embryonic fan (highlighted in grey). Data were not available for some debris flows because the previous debris flow had knocked out the instrumentation at the gauge locations. The rainfall and stage data are previously reported in McCoy et al. (2012). 
Table 2

TLS uncertainty values for permanent control points ${ }^{a}$

\begin{tabular}{|c|c|c|c|c|c|c|c|c|c|c|c|c|c|c|}
\hline CD & UM & $\begin{array}{c}\mathrm{S} 1 \\
(\mathrm{~mm})\end{array}$ & $\begin{array}{c}\mathrm{S} 2 \\
(\mathrm{~mm})\end{array}$ & $\begin{array}{c}\mathrm{PE} \\
\mathrm{S} 1-\mathrm{S} 2 \\
(\mathrm{~mm})\end{array}$ & $\begin{array}{c}\text { S3 } \\
(\mathrm{mm})\end{array}$ & $\begin{array}{c}\mathrm{PE} \\
\mathrm{S} 1-\mathrm{S} 3 \\
(\mathrm{~mm})\end{array}$ & $\begin{array}{c}\mathrm{S} 4 \\
(\mathrm{~mm})\end{array}$ & $\begin{array}{c}\mathrm{PE} \\
\mathrm{S} 1-\mathrm{S} 4 \\
(\mathrm{~mm})\end{array}$ & $\begin{array}{c}\text { S5 } \\
(\mathrm{mm})\end{array}$ & $\begin{array}{c}\text { PE } \\
\text { S1-S5 } \\
(\mathrm{mm})\end{array}$ & $\begin{array}{c}\text { S6 } \\
(\mathrm{mm})\end{array}$ & $\begin{array}{c}\text { PE } \\
\text { S1-S6 } \\
(\mathrm{mm})\end{array}$ & $\begin{array}{c}\text { S7 } \\
(\mathrm{mm})\end{array}$ & $\begin{array}{c}\mathrm{PE} \\
\mathrm{S} 1-\mathrm{S} 7 \\
(\mathrm{~mm})\end{array}$ \\
\hline \multirow{2}{*}{$X$} & SE & -0.03 & 0.02 & 0.04 & 0.07 & 0.08 & 0.02 & 0.07 & 0.08 & 0.07 & 0.01 & 0.08 & -0.08 & 0.08 \\
\hline & $\sigma$ & \pm 3.42 & \pm 1.01 & \pm 3.57 & \pm 2.03 & \pm 2.03 & \pm 0.71 & \pm 1.90 & \pm 0.70 & \pm 1.90 & \pm 0.86 & \pm 1.11 & \pm 0.70 & \pm 1.11 \\
\hline \multirow{2}{*}{$Y$} & SE & 0.00 & 0.09 & 0.09 & 0.06 & 0.11 & -0.03 & 0.03 & 0.05 & 0.07 & -0.01 & 0.06 & -0.01 & 0.01 \\
\hline & $\sigma$ & \pm 6.36 & 0.79 & \pm 6.41 & \pm 6.36 & \pm 2.43 & \pm 0.94 & \pm 2.48 & \pm 1.30 & \pm 2.48 & \pm 1.50 & \pm 1.99 & \pm 0.80 & \pm 1.70 \\
\hline \multirow[t]{2}{*}{ Z } & SE & -0.03 & -0.02 & 0.04 & -0.07 & 2.65 & -0.03 & 2.59 & 0.04 & 2.59 & 0.01 & 1.85 & 0.02 & 1.64 \\
\hline & $\sigma$ & \pm 1.43 & \pm 0.92 & \pm 1.70 & \pm 1.00 & \pm 1.70 & \pm 1.39 & \pm 1.72 & \pm 0.95 & \pm 1.72 & \pm 1.30 & \pm 1.32 & \pm 1.06 & \pm 1.19 \\
\hline \multirow{2}{*}{$\begin{array}{c}\text { All } \\
(x y z)\end{array}$} & SE & - & - & \pm 0.11 & - & \pm 0.13 & - & \pm 0.07 & - & \pm 0.12 & - & \pm 0.05 & - & \pm 0.10 \\
\hline & $\sigma$ & - & - & \pm 7.53 & - & \pm 7.98 & - & \pm 7.58 & - & \pm 7.57 & - & \pm 7.67 & - & \pm 7.51 \\
\hline
\end{tabular}

a $\mathrm{S} 1$ is the survey from 29 May 2009, S2 is the survey from 27 September 2009, S3 is the survey from 30 May 2010 , S4 is the survey from 03 June 2010, S5 is the survey from 09 July 2010, S6 is the survey from 19 August 2010, and S7 is the survey from 14 July 2011. CD - coordinate direction, $\mathrm{UM}=$ uncertainty measure, $\mathrm{SE}=$ systematic error, $\sigma=$ error standard deviation. Note that all uncertainty values are in millimeters. 
Table 3

Volume of erosion measured from the embryonic fan toe and from the debris flow material eroded from the channel plug after each of the debris flows

\begin{tabular}{ccc}
\hline Date & Fan toe $\left(\mathbf{m}^{3}\right)$ & Channel plug $\left(\mathbf{m}^{3}\right)$ \\
\hline Sept2009 - May2009 & 0 & 125.60 \\
May2010 - Sept2009 & 351.76 & 252.79 \\
June2010 - May2010 & 150.26 & 578.75 \\
July2010 - June2010 & 0 & 914.98 \\
Aug2010 - July2010 & 2.64 & 577.88 \\
July2011 - Aug2010 & 1085.292 & 735.08 \\
\hline
\end{tabular}




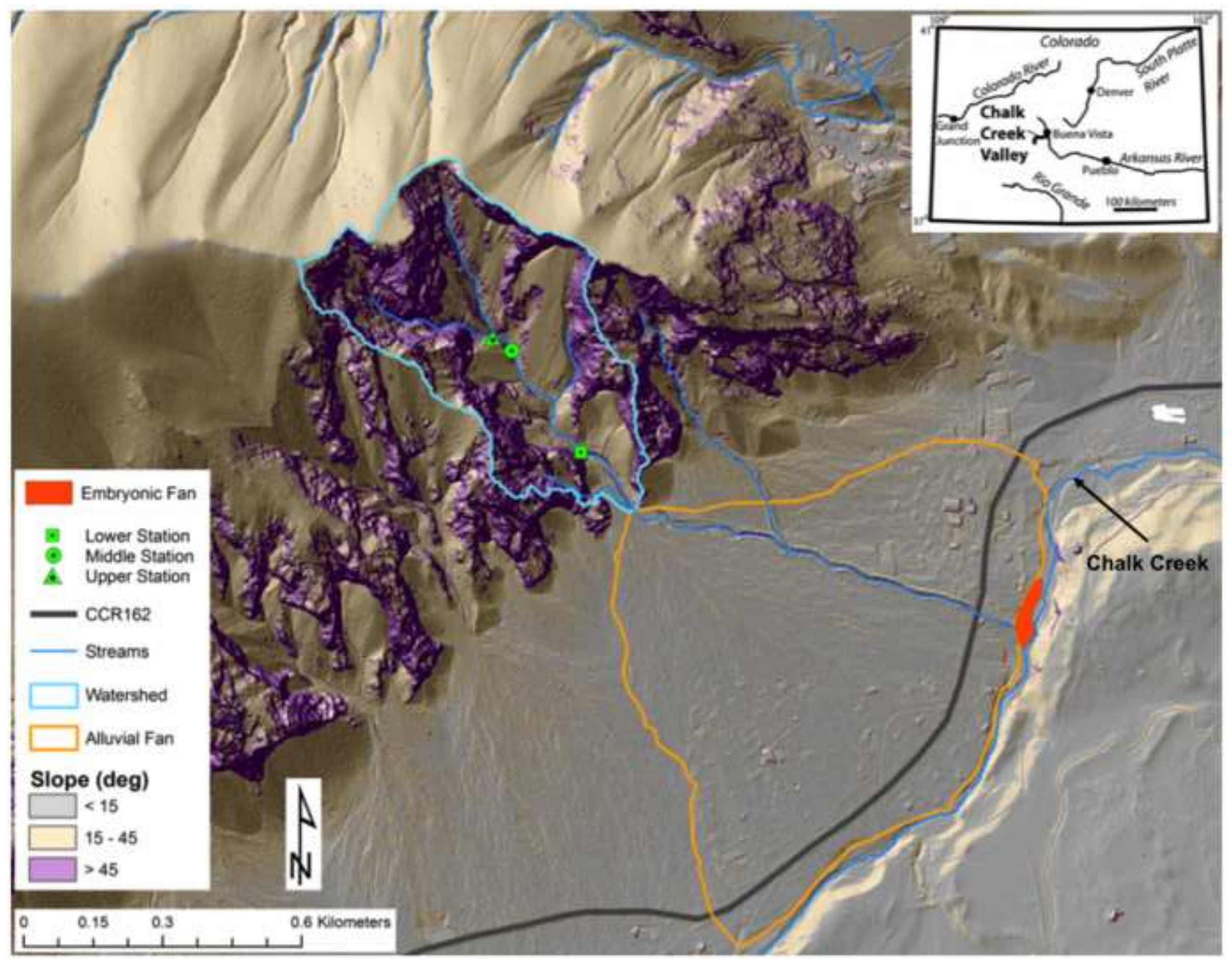

- Middle Station

- Upper Station

CCRI62

Streams

Watershed

Alluviai Fan

Slope (deg)

$<15$

$15-45$

. 

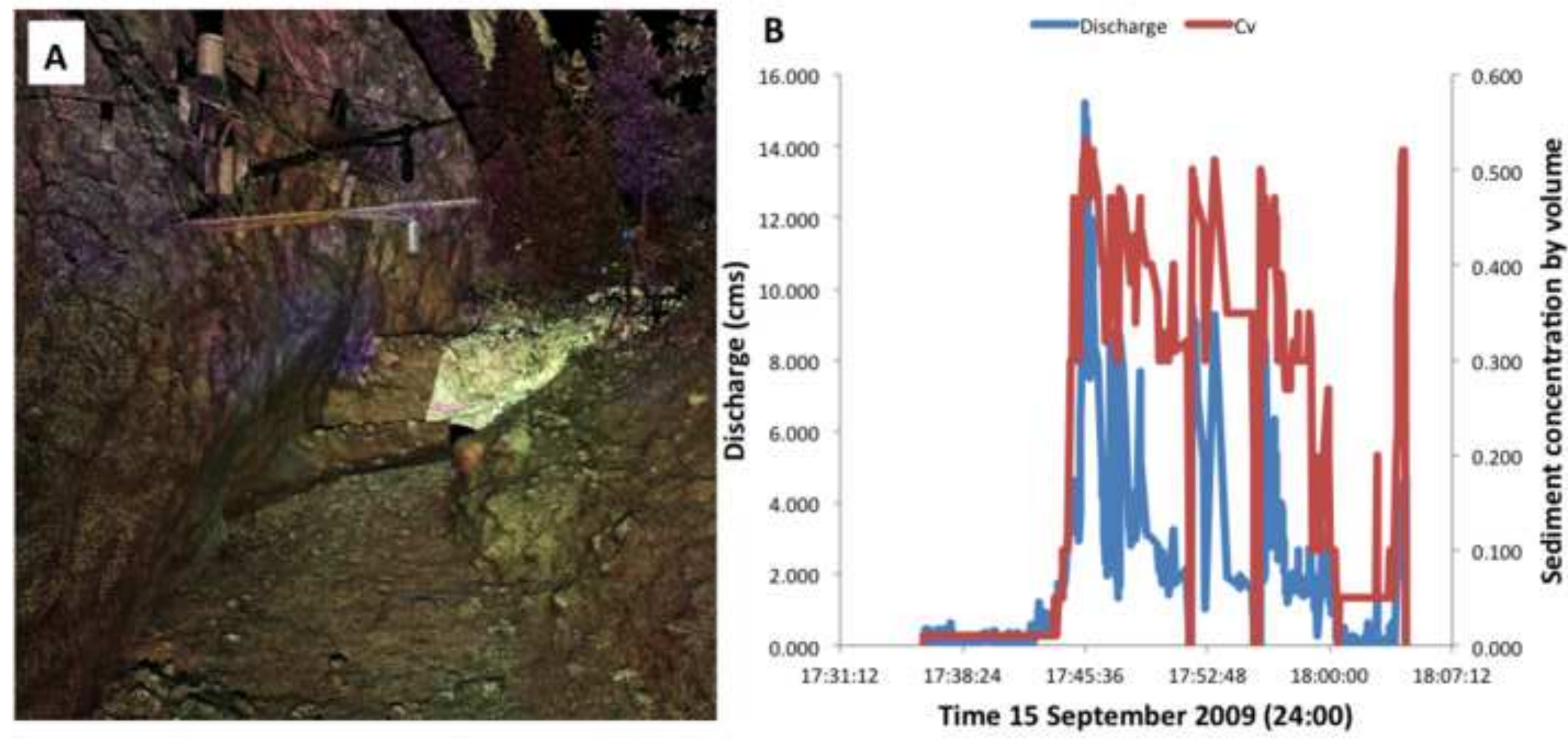

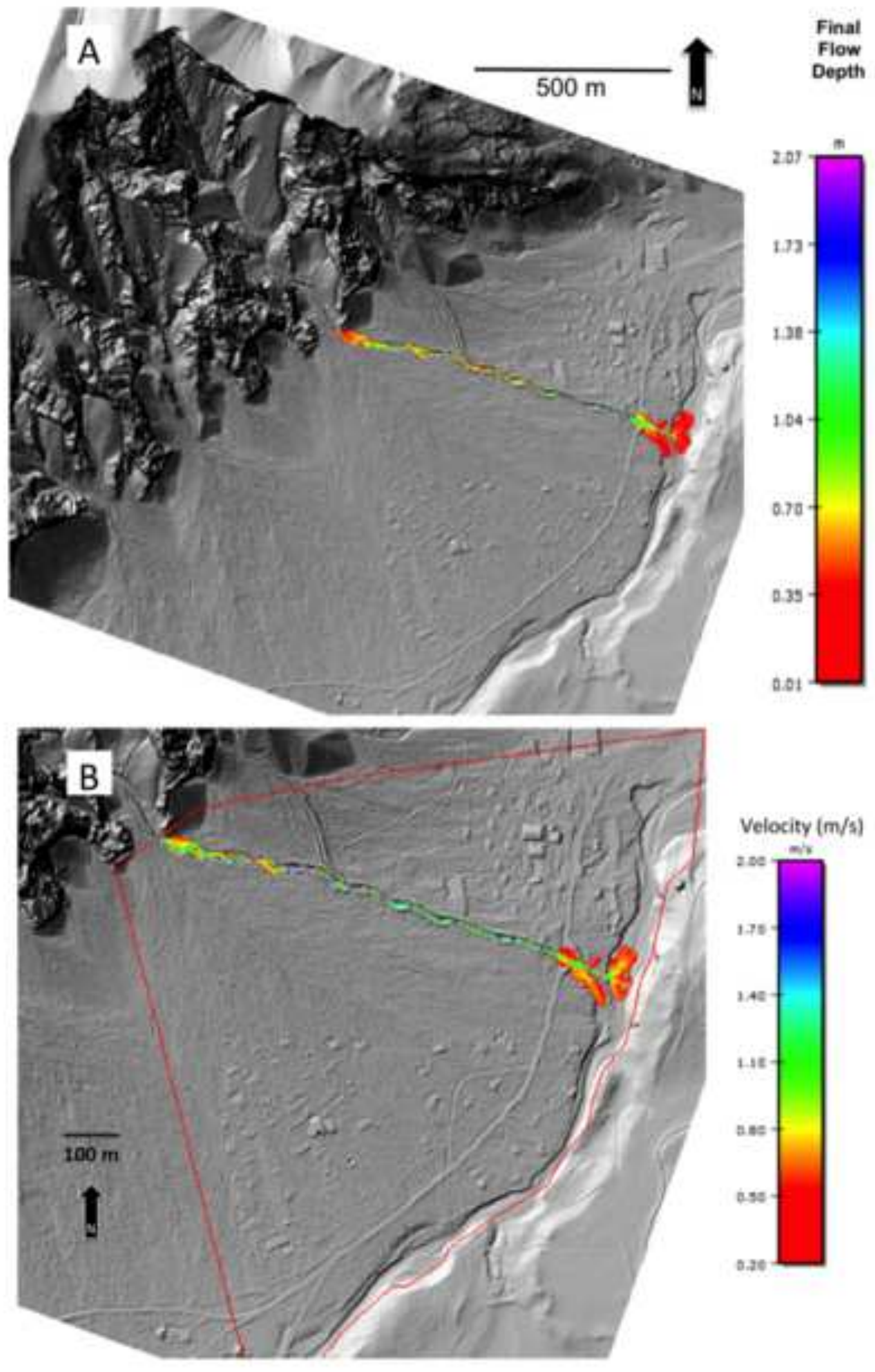

Figure 3

low 


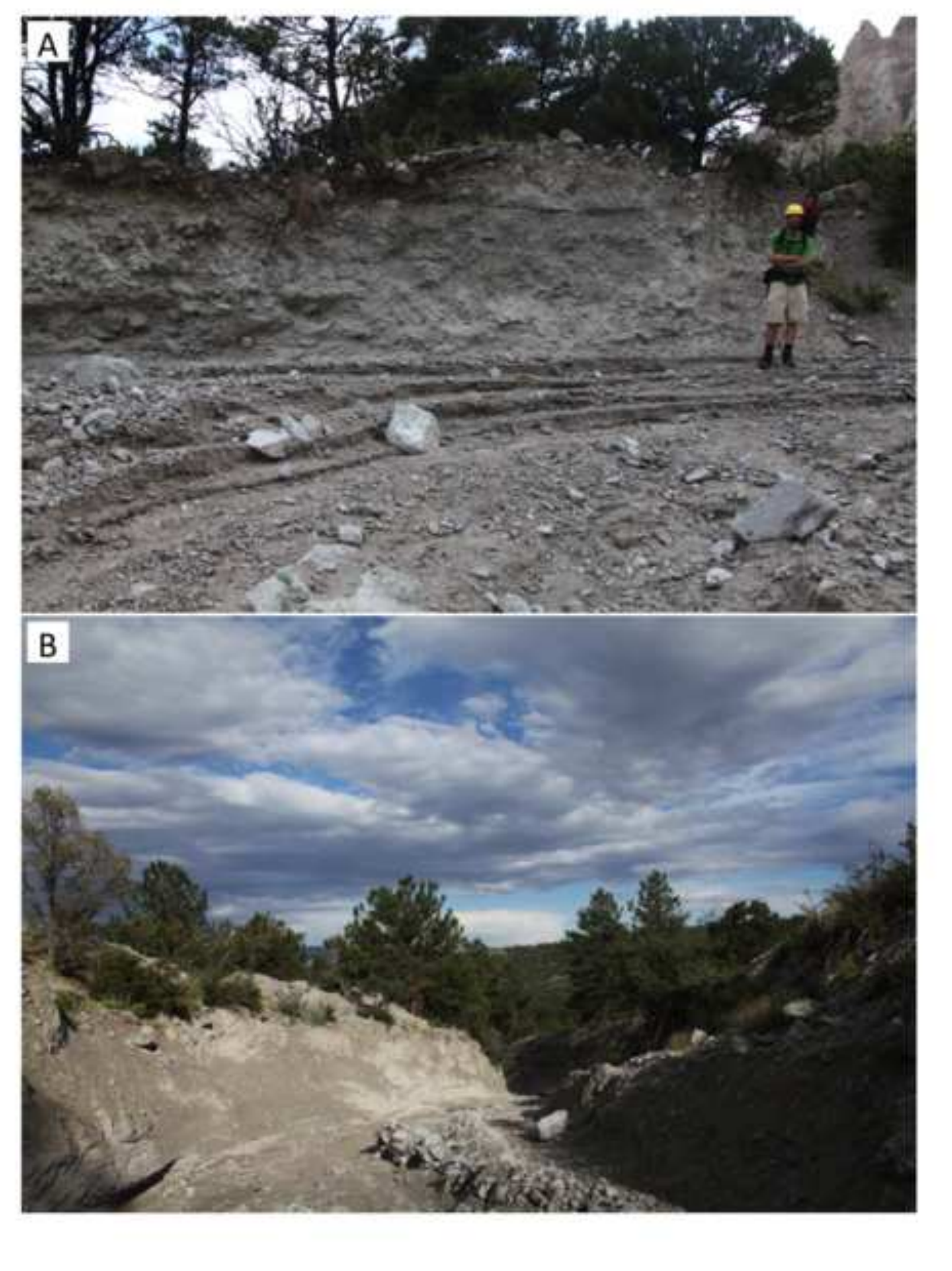

Figure 4

\author{
Figure 4
}

.

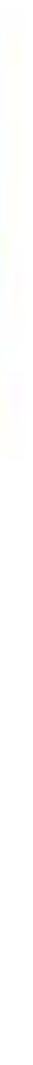
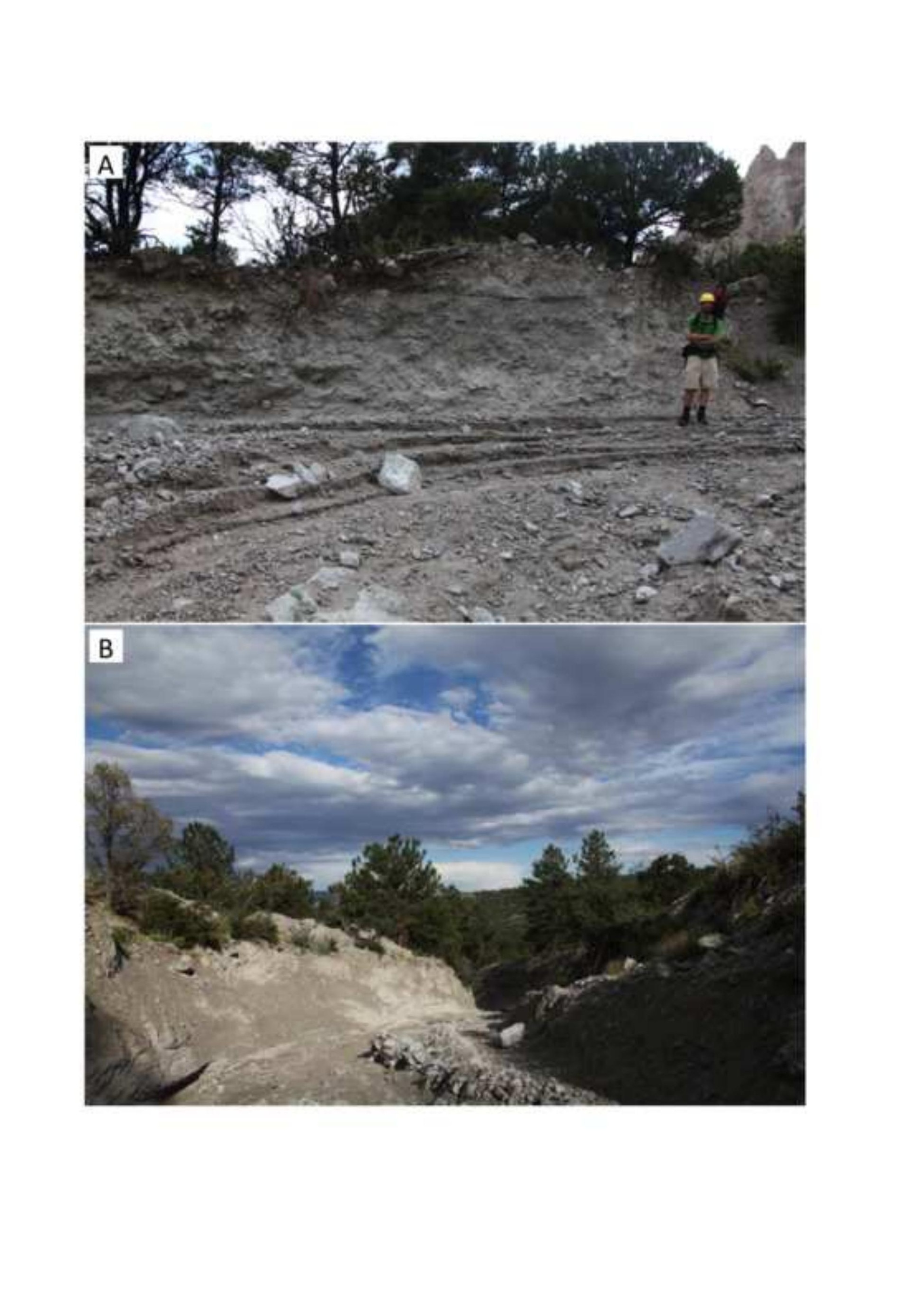

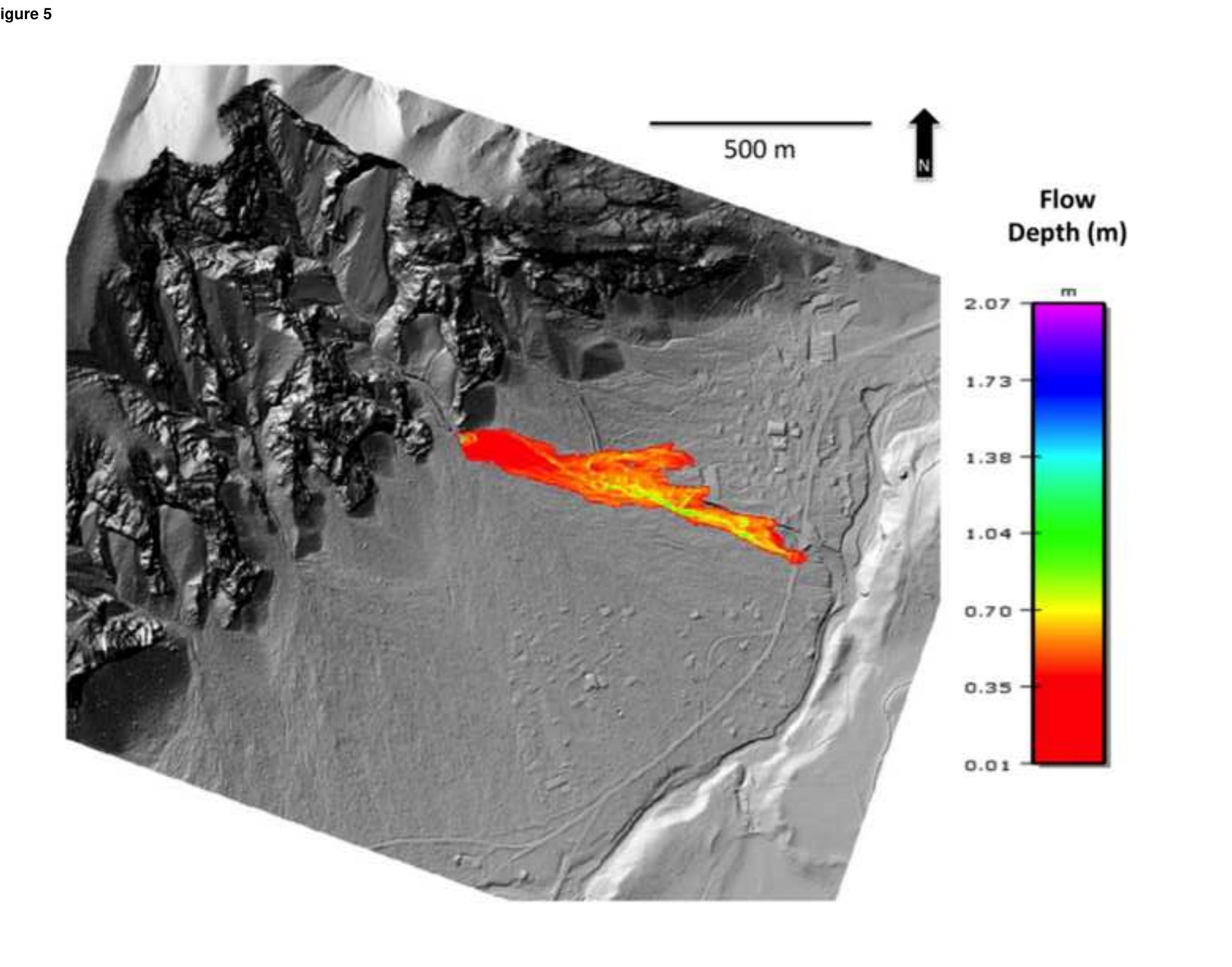


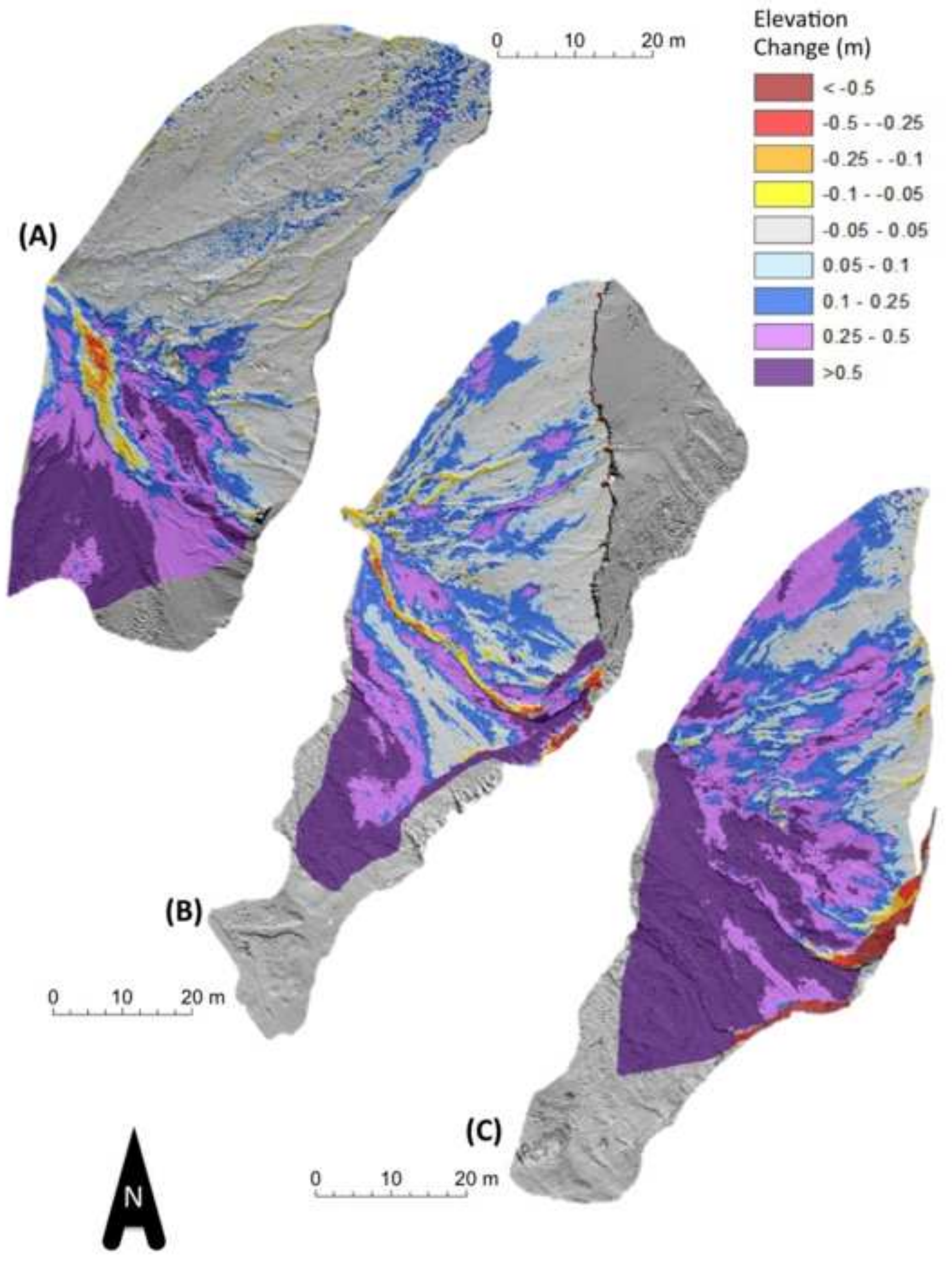

Elevation

Change (m)

$<-0.5$

$-0.25-0.1$

$-0.1--0.05$

$0.1-0.25$

$0.25-0.5$

$>0.5$ 


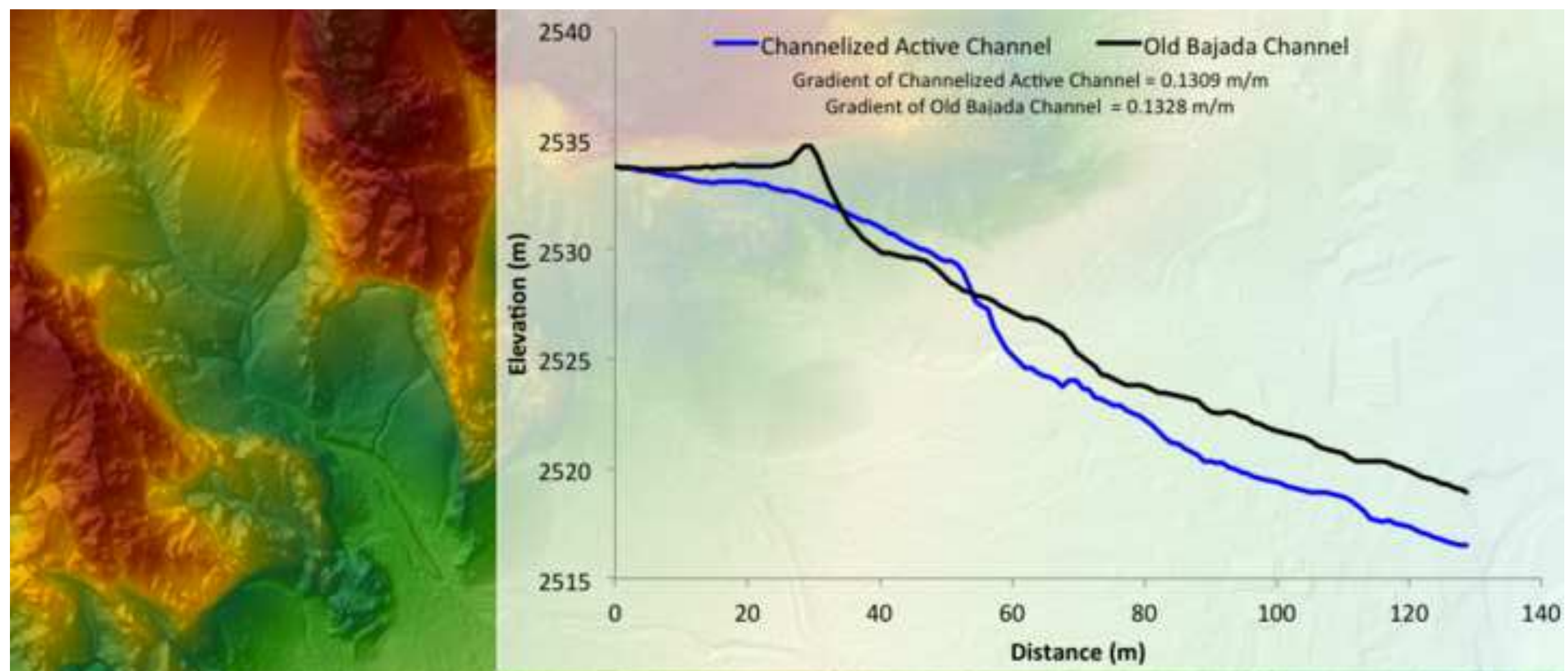

\section{Elevation ( $m$ )} High : 4595.84
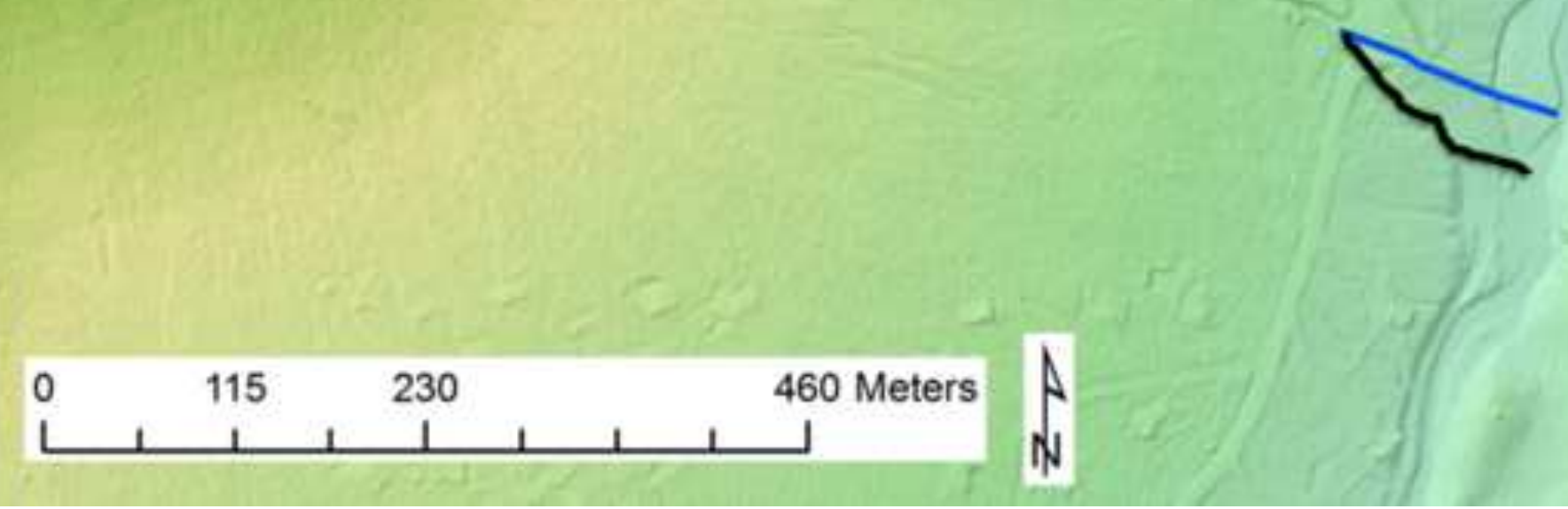

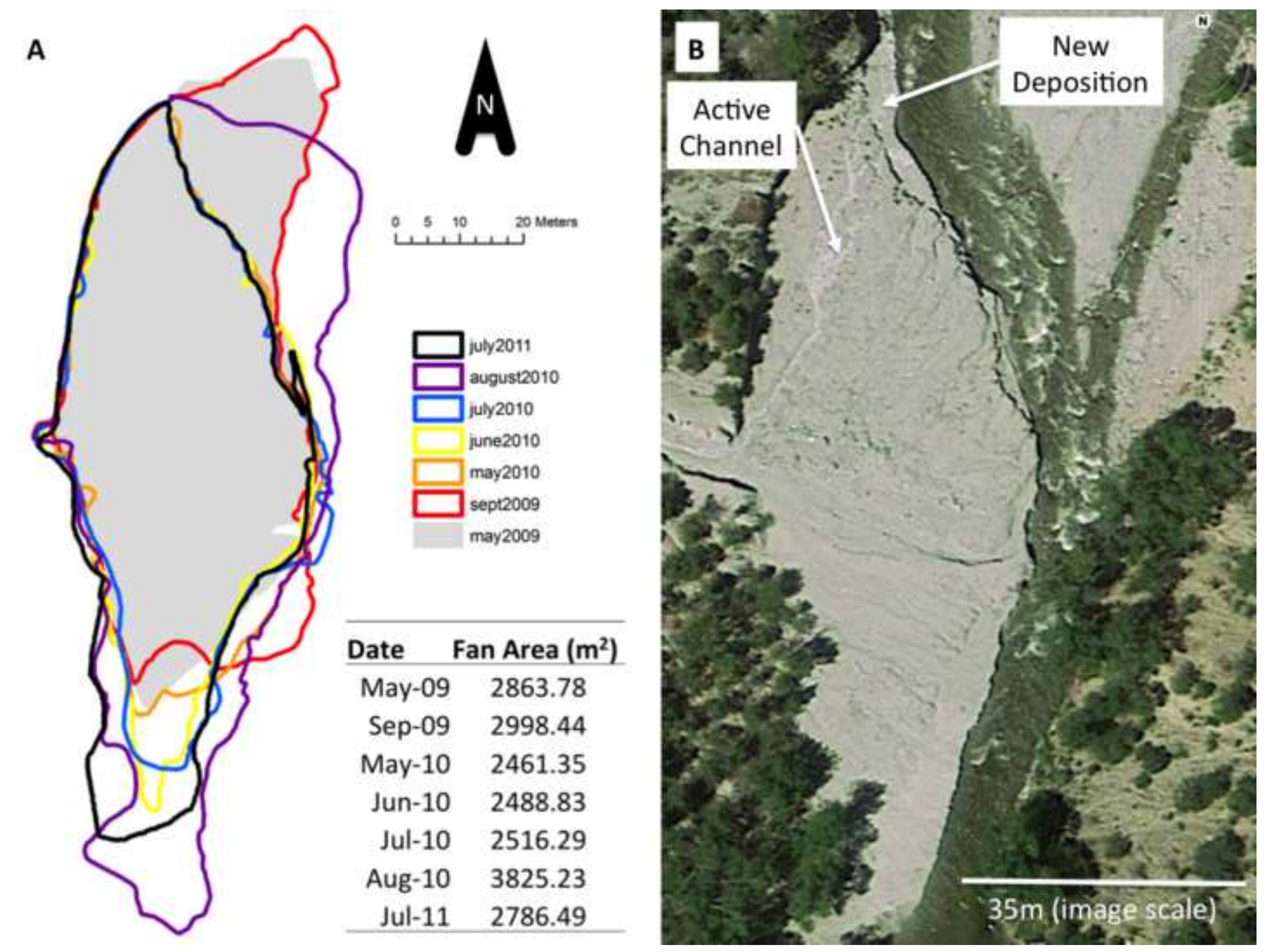

\begin{tabular}{rr} 
May-09 & 2863.78 \\
Sep-09 & 2998.44 \\
May-10 & 2461.35 \\
Jun-10 & 2488.83 \\
Jul-10 & 2516.29 \\
Aug-10 & 3825.23 \\
Jul-11 & 2786.49 \\
\hline
\end{tabular}




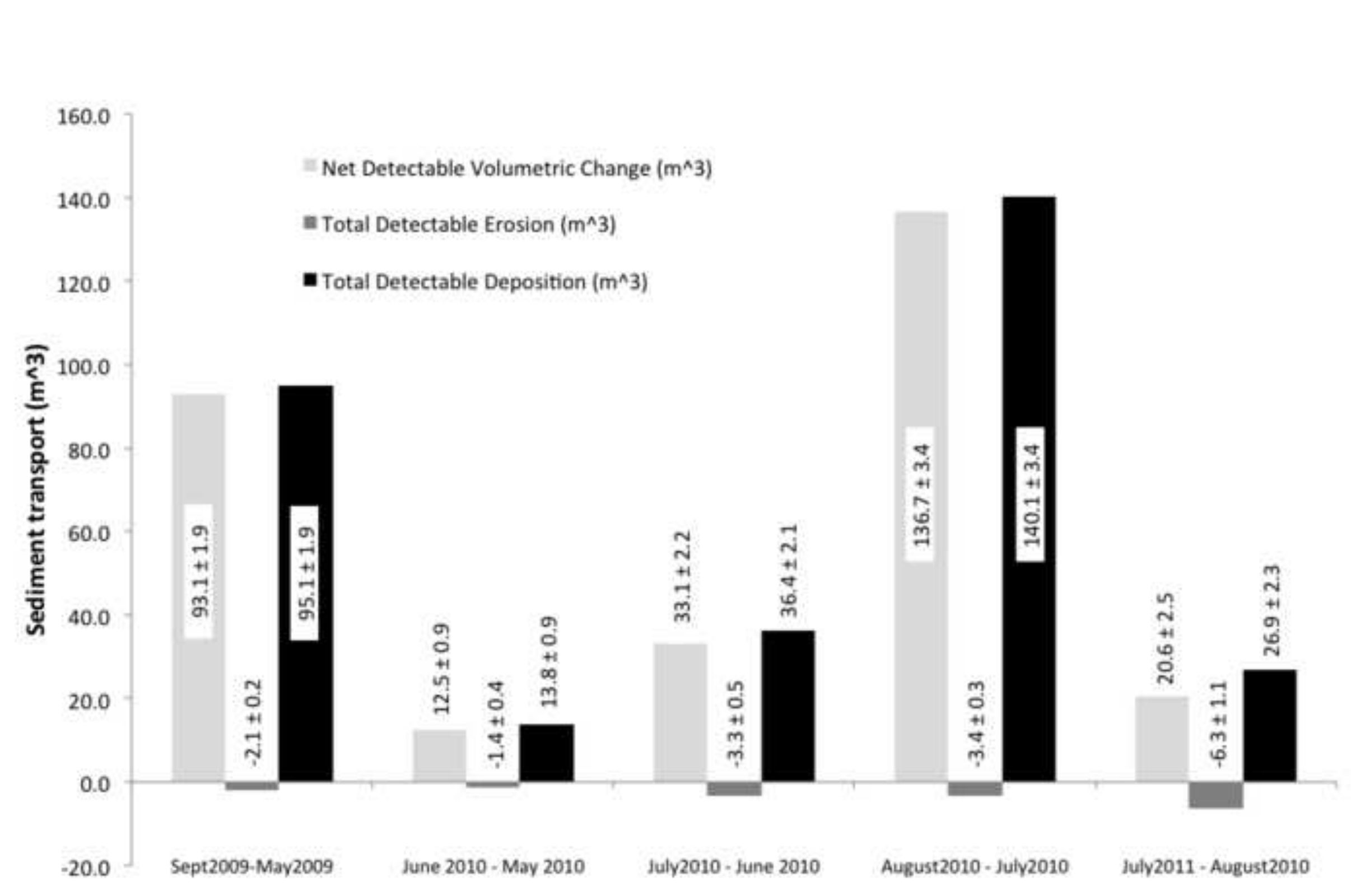

.


Figure 10

- Fan =ichannel

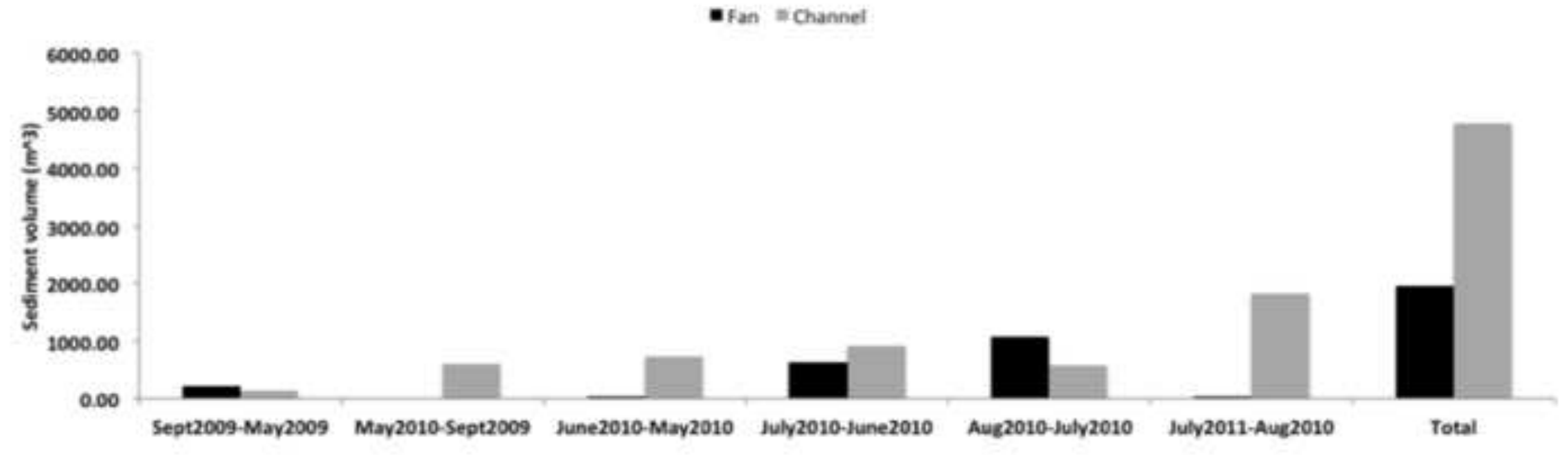

